\title{
Sayfiye Yerleşimlerinin Tarihsel Süreç İçerisindeki Değişimine Yönelik Bir Araştırma: Dragos, Orhantepe Mahallesi Örneği
}

\author{
Resort (Sayfiye) Settlements in the Historical Process: The Case of Dragos, \\ Ortantepe Neighborhood
}

\section{Zümrüt KURU * Zeynep YAZICIOĞLU HALU **}

\begin{abstract}
$\ddot{O}_{z}$ : Arapça kökenli bir sözcük olan sayfiye, yaz mevsimini geçirmek üzere gidilen şehre yakın konut ya da bölgeyi tanımlamak amacı ile kullanılmaktadır. Bu çalışmada sayfiye kültürünün incelenmesi ve kentte kaybolan yapısının ortaya konulması hedeflenmiştir. Bu hedefle, İstanbul'un eski sayfiye yerleşimlerinden biri olan Kartal ilçesine bağl1, Orhantepe Mahallesi'nde bulunan Dragos semtinin 1968-2018 yılları arasında yaşadığı mekânsal değişim incelenmiştir. Çalışmada literatür taraması yapılmış, sayfiye kavramı ile ilgili veriler toplanmış, kuramsal bir çerçeve çizilmiştir. Bunun yanında alan çalışması ve sözlü tarih çalışmaları gibi araştırma yöntemleri izlenmiştir. Çalışma kapsamında; sayfiyenin tanımı/ ortaya çıkışı, sayfiye yerleşimleri/gelişim şekilleri, sayfiye mekânları, kıyı sayfiyelerinin arazi kullanımı ve morfolojisi, Türkiye ve İstanbul'da sayfiye kültürü ve bir sayfiye yerleşimi olarak Dragos'un mekânsal değişimi ele alınmıştır. Çalışmanın sonucunda, sayfiye kültürünün kentin tarihi ve fiziksel yapısı bağlamında önemli bir yere sahip olduğu tespit edilmiştir. Öte yandan sayfiye kültürünün uzun yıllar yaşandığ 1 bir yerleşim olmasına rağmen literatürde yer almayan Dragos'un seçkin bir sayfiye olduğu kanısına varılmıştır.
\end{abstract}

Anahtar sözcükler: Sayfiye, İstanbul, Dragos, Kıyı Mekânının Değişimi

\begin{abstract}
Sayfiye, an Arabic origin word, is used to define the house or the settlement near to the city to spend the summer. The aim of this study has been the culture of sayfiye and the rediscovery of its structure in the city. According to this, the spatial change of the Dragos district, located within the boundaries of the Orhantepe Neighborhood of Kartal district, one of the oldest sayfiye settlements of Istanbul, was examined in the period between 1968 and 2018. In this study, the reference sources were investigated, data was collected regarding the concept of sayfiye and a theoretical frame was sketched out. In addition, the research methods of case study and oral history studies were undertaken. Within the scope of this study the definition and emergence of sayfiye, sayfiye settlements and the forms of development, sayfiye places, the land use and morphology of coastal sayfiyes, sayfiye culture in Turkey and İstanbul, and the spatial change of Dragos were examined. As a result of this study, it was determined that sayfiye culture has an important place in the context of the city's historical and physical structure. Moreover, although it is a settlement where sayfiye culture has been lived for many years it is not included in the literature, and is an exclusive sayfiye.
\end{abstract}

Keywords: Sayfiye, Istanbul, Dragos, Resort Morphology

* Yüksek İç Mimar, İstanbul, zumrutkuru1@gmail.com

** Dr .Öğr. Ü., İstanbul Üniversitesi, Mimarlık Fakültesi, Mimarlık Bölümü, İstanbul. zeynep.yaziciogluhalu@istanbul.edu.tr, https://orcid.org/0000-0003-3783-954X 


\section{Giriş}

Tarih boyunca insanların yaşadıkları ortamdan ve düzenden, kısa veya belirli bir süre için ayrıldığı bilinmektedir. Tatil adı verilen ve rutinden uzaklaşmayı temsil eden bu kavram, zaman içinde toplumların ihtiyaçları ve değişen koşullarla farklılaşmıştır. Bu farklılaşmaya paralel olarak tatil için gidilen ve konaklanan mekânlar da değişim göstermiştir. Bu çalışma kapsamında tatil amacıyla ve yaz mevsimini geçirmek üzere gidilen şehre yakın konut ya da bölgeyi tanımlamak için Sayfiye kavramı üzerinde özellikle durulmuştur. Antik Dönem'den günümüze dünyanın farklı bölgelerinde çeşitli tarihsel dönemlerle tanımlanmış pek çok farklı sayfiye yerleşimi bulunmaktadır. Sayfiye, Türkiye açısından 'tatil' teriminden daha geniş bir anlamı ifade etmekte, özellikle İstanbul çevresinde gelişen yerleşimleri ve konutları, belirli bir hayat düzenini temsil etmektedir. İstanbul'daki sayfiye kültürü Roma Dönemi öncesine kadar dayanmaktadır. Ancak bu çalışmanın kapsamını oluşturduğu anlamda daha geniş halk kitleleri tarafından insanların yaz mevsimini geçirmek için sayfiyelere gitmesi 18. yüzyılın ortaları ile 19. yüzyılın sonları arasında başlamıştır. İstanbul'da ulaşım olanaklarının kolaylaşması ile sayfiye bölgeleri hareketlilik kazanmış fakat 1980'lerle, kentin hızlı büyüme ve şehirleşmesi zamanla sayfiye geleneğinin yok olmasına neden olmuştur.

$\mathrm{Bu}$ çalışmada sayfiye kültürünün incelenmesi ile İstanbul'da kaybolan sayfiye yaşantısının mekânsal değişimi, dönüşümü ve buna paralel kıyının değişiminin ortaya konulması amaçlanmaktadır. Bu doğrultuda, Orhantepe Mahallesi sınırları içinde bulunan Dragos bölgesinin 19682018 yılları arasındaki süreçte yaşadığı mekânsal değişim incelenmiştir. Çok katmanlı bir sayfiye kültürüne sahip olmasına rağmen bu anlamda literatürde yer almayan Dragos bölgesi çalışmanın temelini oluşturmaktadır. Prens adalarına hâkim konumda yer alan Dragos, düşükorta-üst gelir grubunu bir arada bulundurmakta (URL1) ve bu farklı sosyal katmanlaşma sayfiye mekânlarına da yansımaktadır. Dragos, planlı ve kendiliğinden gelişen yerleşimlerin her ikisini de barındıran, özellikle 1950-1970 döneminde kentin çeperinde küçük bir sayfiye görünümündedir. Günümüzde Kartal ve Maltepe ilçelerinin arasında kalmış ve halen farklı özellikleri ile sayfiye kimliğini devam ettiren bir bölgedir.

Çalışmanın yöntemi olan alan çalışmasını beslemek amacıyla bölgenin tarihsel verilerine ulaşılmaya çalışılmış ancak Dragos, Orhantepe Mahallesi'ne ait yazılı literatürde yeterli kaynağa ulaşılamamıştır. Bu sebeple, bölgede yaşamış ve çalışmış olan kişilerle sözlü tarih çalışmaları yapılmıştır. Sözlü tarih çalışmaları kapsamında özellikle kenti deneyimleme üzerine düşünen psikocoğrafya kavramından yola çıkılarak, psikocoğrafik bakış açısı ile Dragos'taki sayfiye yaşantısı incelenmiştir. Mekânların insanlara hissettirdiklerini fark ederek bunları anlatıya dönüştürmek psikocoğrafyanın temelini oluşturmaktadır. Mekânın insan üzerindeki etkilerini inceleyen bu yöntem doğrultusunda, geçmiş y1llarda Dragos'ta yaşayan ve bölgeyi deneyimleyen kişiler ile görüşmeler yapılmış; farklı dönemlerde, farklı pozisyonlarda ve farklı mekân deneyimlerine sahip kişilerin deneyimleri anlatıya dönüştürülerek mimari mekân anlamaya çalışılmış, bu sayede Dragos ve yaşadığı mekânsal değişim irdelenmiştir.

Kıyı gelişimi ve planlamasına yönelik başvurulan kaynaklar, bilinçli olarak (Dragos'ta yerleşimin yoğunlaştığı süreç olması sebebiyle) 1950-1970 sürecinden seçilmiştir. Böylelikle, o dönemdeki güncel sayfiye planlaması ile Dragos kıyı yerleşimi arasındaki ilişki de ortaya konmaya çalışılacaktır.

Dragos sayfiyesinin ve kıyısının fiziksel mekân değişimini ortaya koymak amacıyla, hava fotoğrafları, haritalar ve mimari çizimler kullanılmıştır. İstanbul Büyükşehir Belediyesi şehir haritası arşivinde bulunan altliklardan yararlanarak Dragos, Orhantepe Mahallesi'nin konumu, ulaşım bağlantıları, topoğrafik yapısı belirlenmiş, yerleşimi açıklayan çizimler yapılmış, 
bölgede etkili olan farklı faktörlerin çizelgesi oluşturulmuş ve 1970-1982-2006-2018 yıllarına ait haritalar üzerinde yerleşimin yoğunlaşmasıyla beraber, kıyı mekânının da zamanla nasıl değiştiği ve dönüştüğü ifade edilmiştir.

\section{Sayfiyenin Tanımı ve Ortaya Çıkışı}

İkinci Dünya Savaşı'ndan sonra ekonominin gelişmeye başlaması, şehirleşmenin hızla büyümesi, ulaşımın kolaylaşması, insanların eğitim düzeylerinin yükselmesi, gelirlerinin artması ve boş zaman kavramının önem kazanması gibi durumlar rekreasyon amacı ile gidilebilecek yeni bir faaliyetin ortaya çıkmasına neden olmuştur. İnsanların kısa süreli tatil dönemlerinde ya da yaz tatillerinde şehrin yakın çevresinde boş vakitlerini geçirmek, dinlemek, gezintiye çıkmak ve sağlığını kazanmak gibi nedenlerle gittiği bu faaliyet alanı "sayfiye" olarak tanımlanmaktadır (Özgüç 1977, 143-162).

Geçmişi çok eskilere dayanan sayfiyeler deniz, akarsu kıyıları, dağlar, kırsal alanlar gibi farklı yerleşim bölgelerinde bulunmaktadır ve lokasyon, büyüklük, yapı bakımından farklılık göstermektedirler. İlk çağlarda zenginlerin dinlenmek için sayfiyelere gitmesinin ardından, Orta Çağ' da tedavi amacı ile gidilen sağlık merkezleri olarak kullanılmıştır (Özgüç 1996, 105-121). 17. ve 18. yüzyıllarda gelişmeye başlayan sayfiye yerleşimleri, II. Dünya Savaşı'ndan sonra, orta sınıf tarafından keşfedilmiş ve rekreasyon amacı ile gidilen mekânlar olarak sayıları artmaya başlamıştır (Özgüç 1977, 143-162). Özgüç'ün (1996) belirttiğine göre, özellikle insanların zevk ve moda anlayışlarının değişmesi de farklı yerlere gitme isteğine neden olmuş, bu durum sayfiye yerlerinin gelişmesinde önemli rol oynamıştır. Bir yandan hızlı şehirleşme hareketleri devam ederken insanlar kıyı alanlarına yönelmeye başlamış, bu sayede sayfiyelerin nüfusları artmıştır (Özgüç 1996, 105-121).

\section{Sayfiye Yerleşimleri ve Gelişim Şekilleri}

Rekreasyon amacı ile gidilen sayfiye yerleşimleri, zaman içerisinde fonksiyon değiştirerek gelişmeye devam etmiş ve mekânsal olarak bazı farklılıklar göstermişlerdir.

Sayfiyeler; Gökdeniz (2009), Özgüç (1996), Doğaner (1991)'in de belirttiği gibi yer seçiminde çeşitli coğrafi konumları tercih etmiş; kıyı alanları, kırsal alanlar ve dağlık alanlar sayfiyelerin yer seçiminde öne çıkmıştır.

Sayfiyeler, gelişim şekilleri yönünden ele alındığında ise; Özgüç (1998) sayfiyelerin bulunduğu kıyı yerleşimlerini 'kendiliğinden gelişen' ve 'planlı gelişen' olmak üzere iki başlık altında açıklamıştır (Özgüç 1998, 127-147). Kendiliğinden gelişim gösteren sayfiyeler genellikle yerleşim açısından kıyı alanlarında gelişim göstermiştir ve dünyanın farklı noktasında çok sayıda kendiliğinden gelişim gösteren kıyı sayfiyeleri bulunmaktadır. Bu tip yerleşimlere, 1950'li yıllarda geniş halk kitleleri tarafından bilinilirliği yükselen Fransa'nın Akdeniz kıyısını oluşturan ünlü tatil alanı Cote d'Azur ve İspanya'nın önemli kıyı tatil alanı Costa Brava örnek olarak verilebilir.

Ülkemizdeki sayfiyelerin gelişimi düşünüldüğünde ise, Ege kıyılarında Çeşme ve Bodrum gibi yerleşimler kendiliğinden gelişim göstererek günümüzdeki şekillerini almıştır. $\mathrm{Bu}$ yerleşimler, sahip oldukları turistik tesis ve sayfiye konutları açısından yaz dönemlerinde Türkiye'nin önde gelen, gözde sayfiye mekânlarıdır.

Planlı bir gelişme sonucu ortaya çıan sayfiye yerleşimleri ise, az nüfusa sahip ve ekonomik açıdan zayıf ancak doğal güzellikler bakımından zengin bölgelerin canlılık kazanması için bir geliştirme programı kapsamında tasarlanan yerleşimlerdir. Planlı gelişim ile tasarlanan böylesi yerleşimlere, Fransa'da bulunan bataklık bir alanda konumlanan Languedoc-Rousillon kıyı alanının gelişmesi örnek verilebilir. 1960 yılında Languedoc-Rousillon kıyı şeridinde, hazırlanan proje dâhilinde 6 merkezden oluşan yeni sayfiye yerleşimleri kurulmuştur. Proje 
kapsamında villalar, apartmanlar, tatil köyleri, otel ve kamp alanları tasarlanmıştır (Klemm 1996).

Ülkemizde ise 1980'lerde, özellikle güney ve güney-batı kıyılarında turizmin gelişmesine yönelik pek çok merkez ilan edilmiştir. İlk olarak Antalya'nın güneybatı kesiminde başlatılan 'Güney Antalya Turizm Gelişim Projesi' kapsamında; Olimpos-Beydağları Milli Parkı sınırlarından çıkarılan Beldibi, Göynük, Kemer, Çamyuva ve Tekirova kıyılarında planlı yerleşim alanları oluşturulmuştur (Atik et al. 2006, 165-177).

Sayfiyeler, mekânsal yer seçimlerinin ve planlı/plansız gelişim tiplerinin yanında fonksiyonel gelişimleri yönünden de sınıflandırılmıştır. Lavery (1971) fonksiyonlarına göre sayfiyeleri 8 tipte sınıflandırmıştır (Özgüç 1977, 143-162). Bu sınıflandırma: Merkezi (Büyük) Şehirler, Seçkin Sayfiyeler, Gözde Sayfiyeler, Küçük Sayfiyeler, Tarihi / Kültürel Merkezler, Klş Spor Merkezleri, Kaplıcalar / İ̧̧meler, Günlük Gidilen Sayfiyeler'i kapsamaktadır. Açıklanan 8 tipteki bu sayfiye yerleşmelerinin dışında, şehre yakın konumda olan ve bölgenin fiziki şartlarına göre şekillenen farklı fonksiyondaki diğer yerleşme ise Sayfiye Evleridir. İnsanların tatil yapmak ve dinlenmek için gittiği bu sayfiyeler, şehrin kırsal alanlarına dağılmış durumdadır (Mercer 1960, 74-78). Ekonomik gelirin yükselmesi, ulaşım olanaklarının gelişmesi, eğitim düzeyi ve sosyal imkânların artması gibi durumların yaz aylarında ya da hafta sonları kullanılan sayfiye evlerinin yaygınlaşmasına neden olmuştur. Sayfiye evleri, kullanım bakımından diğer yapılardan bağımsız, bahçeli, iki ya da üç katlı Müstakil Villalar olabildiği gibi, iki tarafı da komşu yapılar ile kapalı olan Sıra Tipi Sayfiye Konutlar veya çok sayıda kullanıcıya hizmet veren Apartman Tipi Sayfiye Konutlar da olabilmektedir.

\section{Kıyı Sayfiyelerinin Arazi Kullanımı ve Morfolojisi}

Kıyı sayfiyelerinde arazinin doğru kullanımı yerleşimin gelişmesini etkileyen faktörlerden biri olmuştur. Özellikle turizm, rekreasyon, ulaşım ve yerleşim gibi faaliyetlerden meydana gelen bu tip bölgelerin kendilerine özgü bir morfolojisi vardır, bu sayede diğer yerleşim alanlarına göre farklılık gösterirler. Kıyı sayfiyeleri çizgisel özelliğe sahip olup, kıyı boyunca odaklaşmış şehirsel bir yerleşimdir ve bu yerleşimlerdeki yapılaşma, merkezi çekirdekten dişarıya doğru $180^{\circ}$ olarak kendisini gösterir. Sayfiyelerin morfolojileri aynı zamanda yerleşimin fonksiyonunu yansitır (Özgüç 1998, 127-147).

Alan çalışması olarak seçilen Dragos, Orhantepe Mahallesi'nin de özellikle 1950-1970 döneminde en önemli imar faaliyetleri içinde olması sebebiyle; Barrett'ın (1958) ve Lavery'nin (1974) sayfiye yerleşmelerindeki arazi kullanım modelleri, alanın incelenmesi için altlık oluşturmaktadır (Fig. 1-2).

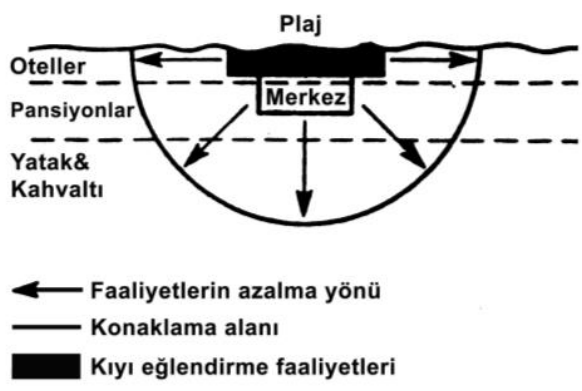

Fig. 1. Deniz kıyısı sayfiyeleri için hazırlanan bir gelişme modeli (Barrett 1958)

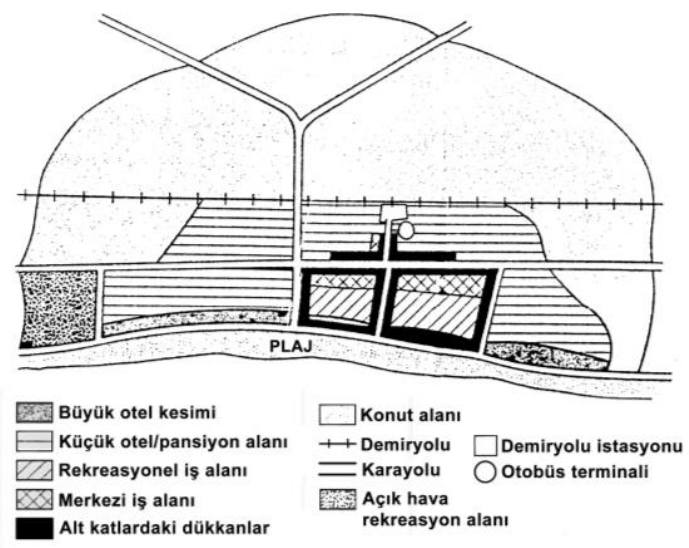

Fig. 2. Bir kiy1 sayfiyesinde arazi kullanım modeli (Lavery 1974) 
Barrett (1958) bir kıyı yerleşmesinde kıyı ve kıyıdaki faaliyetlerin yerleşmenin omurgasını oluşturduğunu belirtmektedir. Kıyıdan ve plajdan uzaklaşıldıkça faaliyetlerin ve mekânsal gelişmenin azaldığını, konaklama alanlarının da kıyı ile arasındaki mesafenin artmasına paralel sundukları hizmetlerin değiştiğini göstermektedir (Fig. 1).

Kıyı sayfiyelerinin gelişimine yönelik daha gelişmiş bir model öneren Lavery'nin (1974) modelinde konaklama alanları, konut alanları ve iş alanlarının sayfiye yerleşimindeki dağılımları ve sayfiye yerleşiminin demiryolu ve karayolu bağlantıları da detaylı bir şekilde belirtilmektedir. Özgüç (1998), Barrett (1958) ve Lavery (1974)'nin önerdiği kıyı sayfiyelerindeki arazi kullanımını üç zon şeklinde açıklamıştır (Fig. 2).

Rekreasyonel İş Alanı: Turistlere yönelik olan bu kullanım şekli otel ve dükkânlardan oluşmaktadır. Mevsimlik olarak hizmet veren bu mekânlar, turistlerin olmadığı dönemlerde aktif değildir.

Ticari Zon: Rekreasyonel amacı olmayan ve bölgede daimi yaşayan yerleşim sakinlerine hizmet eden mekânlardır. Banka, ofis, eczane, market vb.

Kопиt Zопи: Yerleşim sakinleri ve turistler tarafından kullanılır. Kıyıya paralel doğrultuda bir yerleşim düzeni vardır. Konaklama üzerine kurulu olan bu yerleşimlerin kıyıya en yakın noktalarında otel ve pansiyonlar yer alır, kıyıdan uzaklaştıkça konut alanlarından oluşan kesim görülür.

Bir kıyı sayfiyesinin mekânsal gelişme yönü, arazi kullanışı ve morfolojisi Özgüç'ün (1998) belirttiği gibi şu etmenlerle şekillenmektedir;

Plajın büyüklüğü ve biçimi: Falezli bir kıyı alanındaki gelişme içerilere doğru uzanırken, dümdüz bir plaj kenarında konumlanan yerleşim kıyı boyunca her iki yönde gelişim gösterir. $\mathrm{Bu}$ yapılaşma şekli düşük yoğunluklu, yükseltisi az ve oldukça pahalıdır.

Yerleşimin turizm dışı fonksiyonları: Liman faaliyetleri, balıkçllı ve sanayi gibi fonksiyonlar.

Kıyı sayfiyelerinin belirli özellikleri: Yerleşimin fiziksel çekiciliği, ulaşım yolları, demiryolu hattı veya hava limanına sahip olması gibi.

Özgüç'ün (1998) belirttiğine göre, kıyıdan içeriye doğru gelişen paralel yapılaşmanın bazı olumsuz tarafları bulunmaktadır. Birincisi, kıyı alanlarındaki arsa fiyatlarının pahalı olması sebebi ile ilk sıraya ticari ve yüksek katlı yapılar inşa edilmektedir fakat bu kullanım fiziksel ve görsel açıdan doğru bir uygulama değildir, kıyı ve içerideki konut alanları arasında engel teşkil etmektedir. İkincisi ise, bu modele göre ara yollarda meydana gelen araç trafiğinin, konut alanlarından plaja doğru yönelen yayalar için olumsuz etki oluşturmasıdır. Bununla beraber bu yapılaşma doğrusal bir gelişmeye imkân vermektedir ve bu gelişme çevrenin değerini azaltan bir planlamadir.

\section{Türkiye ve İstanbul'da Sayfiye Kültürü}

Türkiye'de sayfiye kültürünün varlığı, Anadolu'daki yerleşimlerin varlığına paralel bir süreç izlemiştir. Roma Dönemi'ndeki deniz kenarı sarayları, hamam ve kaplıcaları, Selçuklu ve Osmanlı Dönemleri'nde de varlığını devam ettirmiştir. İstanbul kıyıları da aynı dönemlerde denizle ilişkili sayfiye mekânlarına ev sahipliği yapmıştır. Sayfiye kavramının geniş kitlelere ulaşması ise, 18. yüzyıl sonrasında gelişen burjuvazi sınıfının sayfiye mekânlarını keşfetmesi ile yeni bir kültürün ortaya çıkmasına neden olmuş; sayfiyelere gitme bir yaşam geleneği ve alışkanlık haline gelmiştir (Bora 2014, 7-12). Zaman içerisinde gelişen ulaşım ve ekonomik olanaklar sebebiyle de sayfiyelere rağbet artmıştır. Yağan \& Binan'ın (2017) belirttiğine göre, İstanbul'da sayfiye bölgelerini etkileyen 3 önemli dönem vardır.

Birinci Dönem; Doğu Roma İmparatorluğu'nun kuruluşundan itibaren 1851 yılında Şirket-i Hayriye'nin kurulmasına kadar geçen süreç. Bu dönemde sayfiye bölgelerinde gelişime rastlan- 
mamıştır. 18. yüzyılda ilk gelişen sayfiyeler Haliç, Kağıthane, Kabataş, Salıpazarı, Ortaköy ve Kuruçeşme gibi kent merkezine yakın alanlardır.

İkinci Dönem; İstanbul'da sayfiye kültürü etkisini yoğun olarak 19. yüzyılda göstermiş, 1851 yılında Şirket-i Hayriye'nin kurulması sonucu artan deniz ulaşımının getirdiği imkânlar ile erişilebilirliği kolaylaşan Boğaziçi kıyı yerleşimleri sayfiye mekânları olarak öne çıkmıştır. İstanbul'da sayfiye yerleşimi 19. yüzyılın sonlarına doğru Boğaziçi'nden Marmara Denizi kıyılarına doğru gelişmiş ve sayfiyeler İstanbul Anadolu yakasında, Kadıköy'den Pendik'e kadar uzanan sahil yolu üzerinde, Avrupa yakasında ise Bakırköy, Yeşilköy ve Florya gözde sayfiye mekânları olmuştur. Bu gelişimin arkasında yatan en büyük etken, 1872 yılında hizmete girmiş olan Sirkeci-Florya ve Haydarpaşa-Gebze banliyö demiryolu hattıdır. İstanbul'un sayfiye bölgelerine ulaşımı sağlayan demiryolu hattı, İstanbul'un mekânsal gelişiminde önemli bir yere sahiptir. Ulaşım imkânlarının gelişmesi ile sayfiye bölgelerine gitmek kolaylaşmış, bu sayede pek çok yeni sayfiye mekânı ortaya çıkmıştır. Anadolu yakasında Haydarpaşa-Gebze demiryolu çevresinde gelişen Fenerbahçe, Göztepe, Erenköy, Suadiye ve Bostanc1; Üsküdar'da ise Çamlıca, Kısıklı, Bağlarbaşı, Altunizade ve Bulgurlu gibi sayfiye mekânları oluşmuştur. Haydarpaşa İskelesi'nin ve Haydapaşa Garı'nın birbirine olan bağlantısı ile deniz ulaşımı demiryolu hattına bağlanmış ve önemini arttırmıştır. Ulaşımın etkisi ile kısa sürede çevresi yerleşimlerle dolmaya başlayan hat, 28 istasyondan meydana gelmiştir (Koday 2000, 139-156). 1914 yılında I. Dünya Savaşı'nın başlamasına kadar geçen 40 yıllık süreçte sayfiye yaşantısı varlığını devam ettirmiştir.

Üçüncü Dönem; 1914 yılından, 1980 yılının başına kadar olan dönemdir. 1930'larda önceki senelere göre sayfiyeye gitme geleneği biraz daha azalmış olsa da, varlığını sürdürmüss, 1930'larda Kalamış ve Yeşilköy tercih edilen sayfiye mekânları olmuştur. Cumhuriyet döneminin getirdiği modern yaşam tarzına paralel açılan plajlar, sayfiye mekânlarının yerleşim tercihlerini de belirler nitelikte olmuştur. Tren istasyonları çevresinde kurulan sayfiye yerleşimleri, bu dönemde yerini plajlarla bağlantılı villa tipi modern konutlardan oluşan yerleşimlere bırakmıştır. Yıl boyunca sayfiyeye gitme zamanını bekleyen İstanbullular için yazın yaklaşması ile sayfiye telaşı başlamıştır. Günümüzde İstanbul'da sayfiye yerleşimi olma özelliğini koruyabilen Adalar, o yıllarda da en çok gidilen yerleşimdir.

Sayfiye mekânlarının gelişiminde etkisi büyük olan Şirket-i Hayriye 1940 yılında iflas etmiş; bu nedenle deniz ulaşımı yerine kara ulaşımı önem kazanmıştır. 1950'lerde karayollarının gelişmesi ve otomobil sahipliğinin artması üzerine Büyükçekmece, Küçükçekmece ve Silivri tercih edilen sayfiye mekânlarıdır. 1980'lere gelindiğinde, İstanbul kenti artık büyümüş, sayfiye alanları kentsel alanlara dönüşmeye başlamış dolayısıyla İstanbul'da sayfiye yaşantısı sona ermiştir. Yeşilköy, Florya, Küçükçekmece, Kartal, Pendik, Kadıköy gibi eski sayfiye yerleşimleri hızlı büyüme ve şehirleşme ile devamlı ikamet haline gelmiş, metropoliten kent alanı içinde kalmıştır. 1990'larla birlikte ise, kentin eski sayfiyeleri de içine alarak büyümesi ile kentin çeperlerinde yeni yerleşimler kurulmuştur (Yazıcıoğlu 2001).

\section{Alan Çalışması: Kıyı Sayfiye Yerleşimi Olarak Dragos, Orhantepe Mahallesi}

Dragos, Orhantepe Mahallesi sahip olduğu doğal ve mimari dokusu ile uzun yıllar sayfiye yaşantısını deneyimleyen bir yerleşimdir. Çalışmanın temelini oluşturan sayfiye kavramının tüm özelliklerini barındırması nedeniyle alan çalışması olarak Dragos kıyı yerleşimi tercih edilmiştir. Dragos, Orhantepe Mahallesi, Kartal ve Maltepe ilçelerinin sınırları içerisindedir. Bu sebeple, tarihsel süreçte Dragos'u ele alırken öncelikle Kartal ve Maltepe'nin mekânsal değişimde rolü olan mekânlar irdelenerek tarihsel bir anlatı yapılmaya çalışılacaktır.

İstanbul'un Anadolu yakasında, Marmara Denizi'nin kıyısında ve Kocaeli Yarımadası'nın güney batısında bulunan Kartal ilçesinin tarihi 6. yüzyıla kadar dayanmaktadır. Geçmiş yıllarda 
küçük bir balıkçı köyü olan ilçe, 1873 yılında Haydarpaşa-Pendik Banliyö Hattı'nın açılması ile canlılık kazanmaya başlamıştır. Eski Kartal Köyü’nde bulunan bahçeli evleri ve kıyısındaki plajları ile İstanbul'un sayfiyelerinden biri olan Kartal, hızlı gelişme ve sanayileşme sonucu 1970'li y1llarda apartmanlaşma sürecine girmiştir. 1947 yılında sanayi bölgesi ilan edilen ilçe, çok sayıda fabrikaların kurulduğu bir yerleşim olmuştur. 1980'den sonra kalabalıklaşan ilçenin, sayfiye özelliğini koruyabilen tek bölgesi Dragos semti kalmıştır (Aksel 1994, 471-73). Kartal'da ilk sanayi yatırımlarından biri olan ve 1929 yılında kurulan Yunus Çimento Fabrikası ile sanayinin gelişimi hızlandırmış, E5 otoyolu ve Kartal-Yalova arabalı vapur seferleri bölgeyi çekici hale getirmiştir. Mutlu Akü, Eczacıbaşı, Siemens, Superlit, Oralitsa, Sunta, Habaş, Seçenler, Aksan Metal gibi fabrikalar 1950-1990 yılları arasında hizmet veren önemli sanayi yapılarını oluşturmuştur. Metal, ahşap, seramik, akü gibi pek çok alanlardaki üretimler bu kurumlarda gerçekleştirilmiştir (Fig. 3) (URL2).

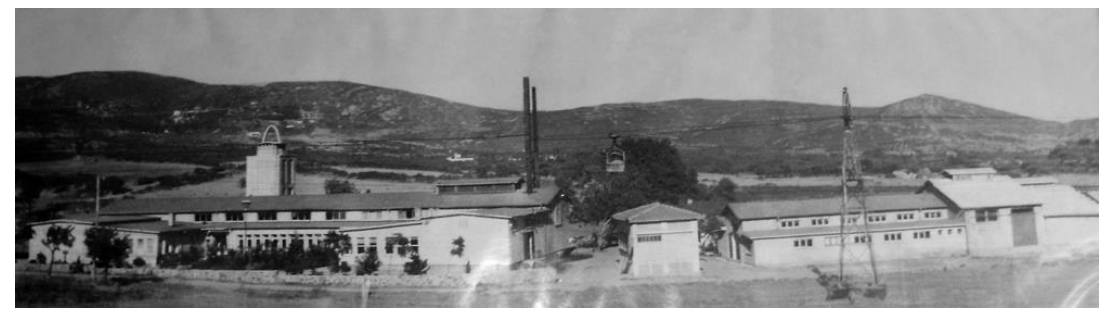

Fig. 3. Kartal Sanayi Yapıları (URL2)

Belçikalı bir firma tarafından Yunus Mahallesi'nde inşa edilen ve 2.000'in üzerinde işçinin çalıştığ fabrika o dönem sanayi yapılarının başında gelmekteydi ve sanayinin sembolü olarak anılmaktaydı. İstanbul için önemli sanayi ve ticaret merkezi olan ilçe, 1990'lı yıllardan itibaren sanayi yapılarının kentin dışındaki alanlara taşınması üzerine sanayi bölgesi niteliğini kaybetmiştir. Kartal ilçesi, 1990'larda terk edilmeye başlayan sanayi yapılarının giderek yıkılması ile önce apartmanlaşma ve sonrasında yüksek katlı yapıların bulunduğu bir bölge haline gelmiştir (URL2).

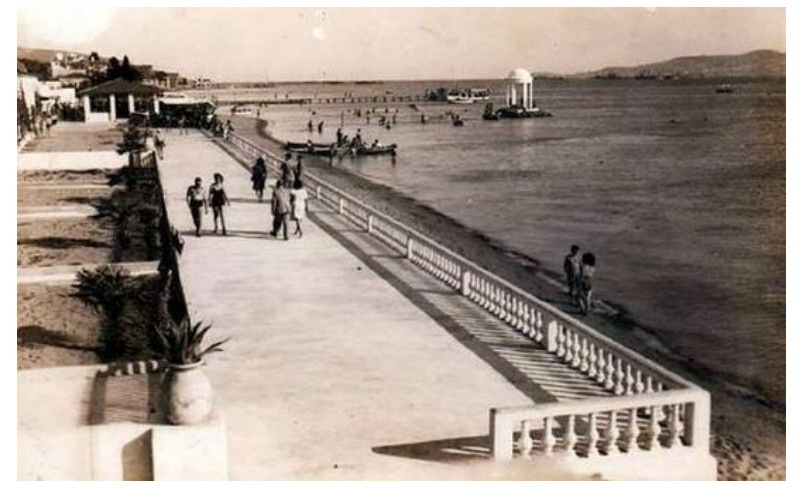

Fig. 4. Süreyya Plajı 1960’lar (URL3)

Dragos semtinin de içinde bulunduğu Maltepe ve Kartal ilçelerinin tarihsel süreçte gelişmesinde önemli rolü olan bir diğer mekân da Süreyya Plajı'dır (Fig. 4). İstanbul'da plaj kültürünün gelişmesini sağlayan, o dönemlerde benzeri olmayan ve bulunduğu çevreye değer kazandıran Süreyya Plaj1, İstanbul'un gözde tesisi olarak bilinir. Bu modern tesisin tarihi süreci; II. Abdülhamid'in seraskerlerinden Rıza Paşa'nın oğlu olan Süreyya Paşa'nın (İlmen) 1939 yılında Maltepe sahilinde sebze yetiştirdiği bahçesinin yerine plaj yapmaya karar vermesi ile başlamıştır. 20 Haziran 1939 tarihinde başlayan çalışmalar, II. Dünya Savaşı ile kesintiye uğramış ve 1946 yılında tamamlanmıştır. 8 Haziran 1946 tarihinde plajın açılmasının ardından, insanların buraya 
kolay ulaşım sağlayabilmesi için TCDD'nın desteği ile bir de istasyon kurulmuştur. Plajın açılışına gelemeyen, dönemin valisi Lütfi Kırdar sonraki günlerde ziyarete gelmiş ve beğenmesi üzerine plajdan Bağdat Caddesi'ne uzanan asfalt bir yol yaptırmış, böylece tesisin caddeye bağlanmasını sağlamıştır. 300 metre uzunluğunda kıyısı bulunan Süreyya Plajı, 80 adet 1. mevki soyunma odas1, 200'den fazla 2. mevki soyunma odası, büfe, gazino, hizmet odaları, 42 odalı otel ve 1 büyük evden oluşuyordu (URL4).

Plajın simgesi, kıyıdan 50-60 metre uzaklıkta bulunan ve denizin ortasındaki kayalıkların üzerine yapılan Bakireler Anıtı idi. 3,5 metre çapında, 4 metre yüksekliğinde, 6 kolon üzerine yerleştirilmiş bir kubbeden oluşan yapının ortasında Venüs heykeli bulunmakta idi. Eski bir inanışa göre, evlenmek isteyen genç kızların Bakireler Anıtı'nı ziyaret ettiği efsanesinden yola çıkılarak yapıldığı söylenmektedir

\section{Dragos, Orhantepe Mahallesi'nin Tarihçesi}

Cevizli tren istasyonundan Köroğlu caddesine kadar devam eden Orhantepe Mahallesi; Doğu Roma İmparatorluğu'ndan, Selçuklulara, Osmanlı İmparatorluğu'ndan Cumhuriyet Dönemi'ne ve II. Dünya Savaşı'ndan Türk siyasetine yön vermiş isimlere kadar içinde barındırdığı tarihi ile önemli bir yerleşim alanıdır (Anonim 2005).

Bizans dönemine ait kalıntıları barındırması nedeni ile korunması gereken tarihi bir semt olan Dragos; Bizans İmparatoru Alexios ve Anadolu Selçuklu Sultanı Süleyman Şah'ın, 1081 yılında imzaladıkları antlaşma sonucu Bizans ve Türklerin ilk resmi sınır çizgisi olarak tarihimize geçmiştir. Yerleşimin kurulmasından sonra 'Orhantepe' olarak kullanılan ismi ise, 1330 yılında Orhangazi’nin Bizans İmparatoru III. Andronikos'u bozguna uğrattığı savaşın Dragos tepesinde gerçekleşmesi üzerine verilmiştir (Anonim 2009, 26-27).

Denizden 107 metre yükseklikteki Dragos Tepesi (Orhantepe) üzerine kurulmuş, yeşillikler içerisinde bulunan ve önünde pırıl pırıl denizi olan Dragos, 1940 yılının son dönemlerinde imar faaliyetleri içine girmiştir. 1947 yılında bazı bakan ve milletvekillerinin kurduğu "İstanbul'da Ankara Evleri Konut Yapı Kooperatifi", Orhantepe'de parselasyon yapmış ve villa tipi konut tipolojileri içeren mimari projeler hazırlatmıştır. Bunların sonucu olarak 1950'li yıllarda tepede iki katlı yazlık villaların sayıları hızla artmıştır. Dragos tepesi, 1950'lerde yeşillikler arasındaki villaları, deniz kulübü, özel plajı ve çam koruluğu ile seçkin bir sayfiye yerleşimi olmuştur. Bölgeye ulaşım, çoğunlukla Haydarpaşa-Pendik banliyö tren hattı ile ulaşılan Cevizli banliyö tren istasyonundan sağlanmaktaydı 1960 yılından sonra Cevizli bölgesinin gecekondulaşması sonucu, kooperatif ortaklarından bazılarının arsalarını satmaları sonrasında yeni parselasyon işlemleri yapılmıştır. Dragos'un Maltepe tarafı ve Kartal'a bağlı bölümü sahil boyunca sanayi bölgesine dönüşmeye başlamıştır. Maltepe'den Dragos tepesinin güneydoğusuna kadar uzanan sahilde AGA, Vinileks, kereste, un fabrikası ve imalathaneleri kurulmuştur (Anonim 1994).

1970’lere doğru gelindiğinde tepenin güneydoğu eteklerinde, kamu kurumlarına ait, önceleri çadır ve karavan tipi geçici kamp alanları olarak gelişen yerleşimler sonraları aynı kamu kurumlarına ait kalıcı kamp ve dinlenme tesisleri olarak inşa edilmiştir. 1980'lerde Dragos, sayfiye mekânı olma özelliğini farklı kesimlerden kullanıcılarla sürdürmüştür. Bölgeyi etkileyen büyük çaplı değişim 1990'larda gerçekleşmiş; 1990'ların başında tepenin önünden geçirilen sahil yolu yalıları, köşkleri denizden uzaklaştırmıştır. Binaların sayıları artmış, çevredeki sanayinin oluşturduğu deniz kirliliği ve inşa edilen sahil yolu doğal plajları yok etmiş, denize girme imkânı da böylece yok olmuştur. Bu süreçte semtin villa tipi konutlarının sahipleri el değiştirmiş, kullanıc1ların Dragos'taki aidiyet duygusu azalmıştır. Yaşanan bu değişimlerin Dragos'un toplumsal ve ekonomik yapısında farklılıklara neden olmasına rağmen günümüzde de İstanbul'un içinde halen sayfiye hayatının villa tipi konutlar ve kamu kurumlarına ait dinlenme ve eğitim tesisleri ile devam ettiği söylenebilir. 
Sahip olduğu konumu ile Marmara Denizi'ndeki Prens Adaları'nın bir uzantısı olan ve doğal güzellikleri ile ünlü isimlerin de dikkatini çektiği bir semt olan Dragos; Ali Sami Yen, Lütfi Kırdar, Hasan Ali Yücel, İsmet İnönü, Muhsin Ertuğrul, Nihat Erim, Melih Esenbel, Vehbi Koç, Zeki Müren, Can Yücel, Halil İnalcık ve Ajda Pekkan gibi tanınmış isimlerin yaşadığı bir yerleşim alanı olmuştur.

\section{Dragos, Orhantepe Mahallesi’nin Konumu ve Fiziksel Özellikleri}

Marmara Denizi kıyısında, Kartal ve Maltepe ilçeleri arasında konumlanmış olan Dragos, doğal güzellikleri ile dikkat çeken bir kıyı yerleşimidir. Bağlı olduğu Kartal merkeze 4 km uzaklıkta, İstanbul şehir merkezine ise $18 \mathrm{~km}$ uzaklıkta bulunmaktadır (Fig. 5, 6, 7).

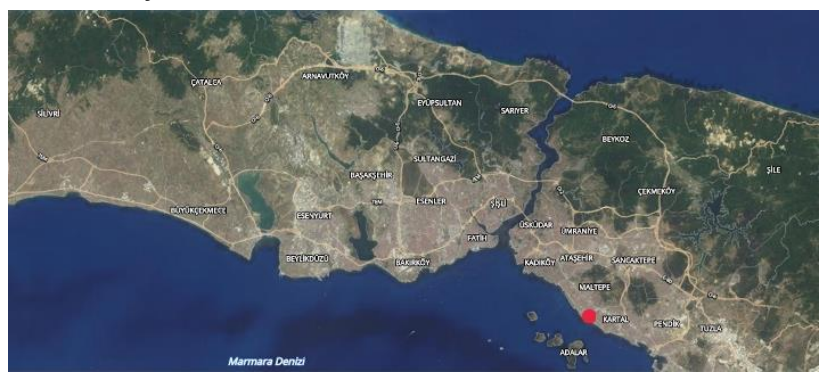

Fig. 5. İstanbul'da Orhantepe Mahallesi'nin konumu (yazar tarafindan işaretlenmiştir 2018)

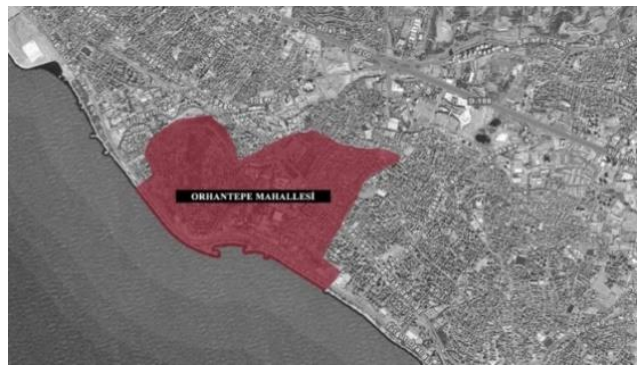

Fig. 6. Orhantepe Mahallesi'nin konumu (yazar tarafindan işaretlenmiş̧ir 2018)

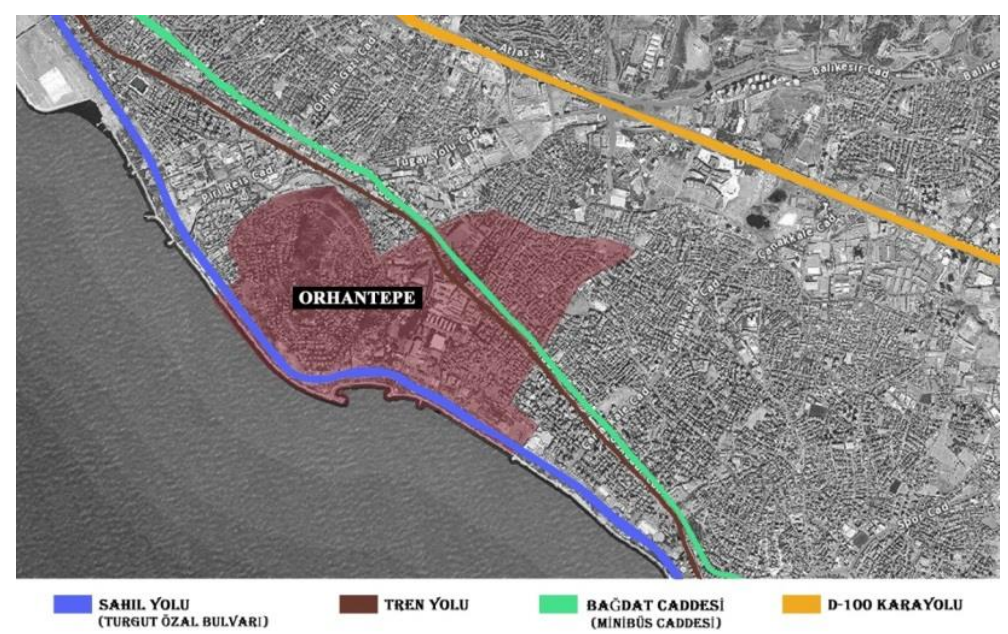

Fig. 7. Orhantepe Mahallesi'nin Ulaşım Analizi (yazar tarafından üretilmiştir 2018)

Doğu yönünde tren yolu ve minibüs yolu, batı yönünde sahil yolu ile sınırlanmış olan Dragos yerleşiminin topoğrafik özellikleri incelendiğinde oldukça eğimli bir yapıya sahip olduğu görülmektedir (Fig. 8). Tepe noktasında $125.000 \mathrm{~m}^{2}$ 'lik özel orman alanı bulunan Dragos, ormanlık alan ve yakın çevresi ile doğal sit alanı ilan edilerek koruma altına alınmıştır. Kartal'ın değerli alanlarından biri olan tepe, tipine az rastlanan bitkileri bulundurmaktadır. Jeolojik olarak incelendiğinde ise, bölgenin magmatik bir yapısı olduğunu ve granit taşlarından oluştuğunu söylemek mümkündür. 


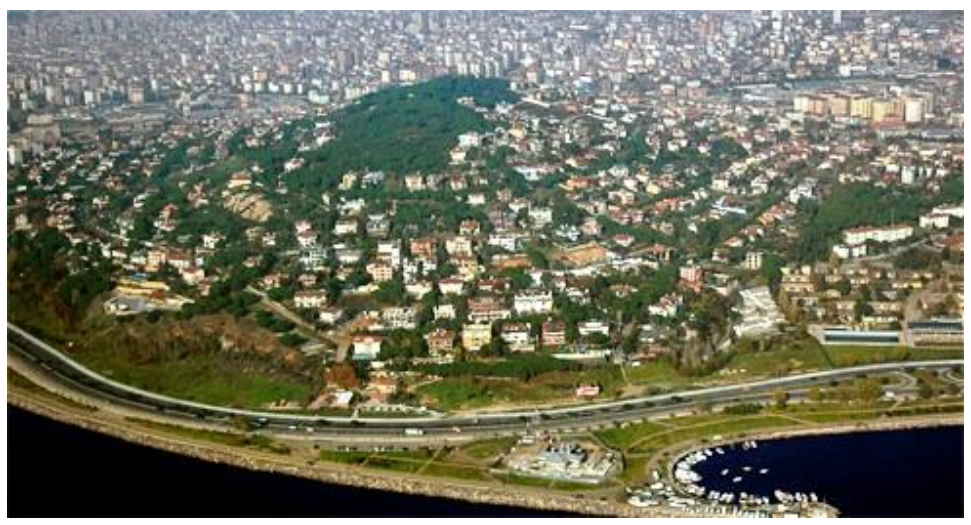

Fig. 8. Dragos, Orhantepe Mahallesi (URL5)

\section{Dragos Koruma Amaçlı Uygulama İmar Planı ve Doğayı Koruma Derneği}

Doğanın rant uğruna yok edilmesini önlemek üzere bir araya gelen duyarlı Dragos sakinleri, yerleşimin doğal ve mimari dokusunun yaşatılması amacı ile 1996 yılında "Dragos Doğayı Koruma Derneğii' ni kurmuşlardır. Derneğin en önemli ilkesi, Dragos'un düşük nüfus ve yap1 yoğunluğunun korunmasını sağlamaktır. Bölgede yeşili yok ederek imar kurallarını çiğneyenler ile büyük mücadeleler veren dernek, hukuk yolu ile önemli başarılar elde etmiştir. Dragos; tepesindeki 125 dönümlük ormanı, sahili, yeşil alanları, 2 katlı bahçeli villaları ile doğal yaşamın sürdüğü bir yerleşim bölgesidir. 1992 yılında, beldenin \%90 oranındaki alanı Kartal Belediyesi'ne, kalan \%10 oranındaki sahil yapı adası ise Maltepe Belediyesi'ne bağlanmıştır. İki farklı belediyeye bağlı olması sonucu bazı sorunlar ortaya çıkmıştır (Göksel 2018).

İmar kurallarına uymayan yapılaşmanın önüne geçebilmek için İdare Mahkemelerinde 25 adet dava açan ve bu davalarda olumlu sonuçlar elde eden dernek, Dragos tepesinin bahçeli nizam uygulamasından bitişik nizama geçmesini önlemiş; emsal artış planı olarak kıyı şeridine yüksek yapılaşma verilmesi, alüvyon zeminlerin ve dere yataklarının imara açılması gibi yanlış uygulamalara karşı çıkarak Dragos'u koruma altına almıştır.

1990'ların sonlarında, Dragos Tepesi'nin çöp toplama işlemi atlı araba ile yapılırken, belediyeden bölgeye çöp kamyonları gönderilerek modern bir uygulamaya geçilmiş; İSKİ ile yapılan çalışmalar sonucu beldeye temiz su verilmiş ve bölgenin kanalizasyon bağlantısı yapılmıştır. İGDAŞ'a yapılan müracaatlar neticesinde ise Dragos tepesine doğal gaz bağlanmış ve daha yeşil bir Dragos için belediye ortaklığı ile ağaç dikim ve temizlik kampanyaları düzenlenmiştir (Göksel 2018).

2368 sayılı Kültür ve Tabiat Varlıklarını Koruma Kanunu gereğince hazırlanan Koruma amaçlı uygulama imar planları, doğal ve çevresel değerlerin sürdürülebilirliğinin sağlanması ve bu alanların korunması amacı ile hazırlanır. Bu planlar hazırlanırken öncelikle bölgenin arkeolojik, tarihi, doğal, mimari, demografik, kültürel, sosyoekonomik, mülkiyet ve yapılaşması hakkındaki gerekli araştırma ve çalışmalar yapılmalıdır (TMMOB 2009). Bu bağlamda çalışma alanı değerlendirildiğinde, Dragos, 11 Kasım 1999 tarihinde resmi gazetede yayınlanarak Dragos Doğayı Koruma Derneği'nin girişimi ile doğal sit alanı olarak ilan edilmiştir. Dernek üyeleri uzun süren çalışmalar sonucunda kapsamlı bir dosya hazırlayarak 22 Aralık 1997 tarihinde Kültür Bakanlığı'na başvurmuş ve yasadışı yapılaşmayı önlemek adına bölgenin doğal sit alanı ilan edilmesini istemişlerdir. Yapılan başvurunun kabul edilmesi ile Dragos tepesinde yer alan özel orman alanı birinci derece sit alanı, bu alanın güneybatısındaki alan ile tepenin güneyindeki sahil boyunca devam eden alan ikinci derece sit alanı, bunun dışında kalan alanlar ise üçüncü derece sit alanı olarak belirlenmiştir. Birinci derece sit alanında, hiçbir şekilde yapılaşmaya izin verilmemektedir fakat koruma kurulunun izni ile rekreasyon amaçlı tesisler 
yapılabilmektedir. İkinci derece sit alanında, turistik tesisler ve hizmet veren yapılara izin verilmektedir. Üçüncü derece sit alanında ise, bölgenin doğal yapısını bozmamak koşulu ile konut inşa edilebilmektedir (URL6).

Dragos'un sit alanı olarak ilan edilmesinin ardından, Dragos Tepesi ve Yakın Çevresi için Koruma Amaçlı Uygulama İmar Planı geliştirilmiştir. Plan, 'İstanbul'un önemli kimlik belirleyicileri olan tarihi kültürel dokusu, peyzaj1, röperleri ve siluet, dinamik koruma prensipleri ile korunmalıdır' ilkesi ve 1999 yılındaki 'Doğal Sit Alanı' kararı doğrultusunda hazırlanmıştır. 1/1000 Ölçekli Dragos Koruma Amaçlı Uygulama İmar Planı 100 hektarlık alanı kapsamaktadır (Kartal Belediyesi 2017).

Dragos tepesi ve yakın çevresi için hazırlanmış olan koruma amaçlı uygulama imar planı dahilinde, plan alanı içerisinde yer alan mevcut yapıların korunmasında ve yeni yapıların inşasında uygulanacak genel şartlar belirtilmiştir. Bölgenin korunmasını sağlamak koşulu ile günübirlik tesislerin yapılmasına izin verilmiștir. Kültür ve Tabiat Varlıklarını Koruma Kurulu'nun görüşü alınarak botanik bahçe, spor faaliyetleri ve kültür-sanat etkinliklerinden oluşan şehir parkı yapılabilmesine karar verilmiştir.

\section{Dragos, Orhantepe Mahallesi’nde Sayfiye Mekânlarının Yerleşimi: Kendiliğinden Gelişen} Yerleşim Olarak Kamplar ve Planlı Yerleșim Olarak Villalar

Önceki bölümlerde açıklandığı gibi yılın belirli dönemlerinde ve belirli zaman aralıklarında rekreasyon amacı ile gidilen sayfiye mekânları, fiziksel çekicilikleri ile keşfedilmiş ve bu özellikleri sayesinde gelişmeye başlamıştır. Bu doğrultuda çalışma alanı olarak belirlenen Dragos semti de öncelikle doğal güzellikleri ile dikkat çekmiş; coğrafi konumu, şehrin içinde yer alması ve tren yoluna yakın konumda olması bölgenin tercih edilmesindeki diğer etkenler olmuştur. İnsanların tatil dönemlerinde fiziksel ve ruhsal olarak dinlenmek, yenilenmek üzere gittiği sayfiye mekânlarından biri olan Dragos, Ankara'dan gelen özel bir grup ailenin sayfiye evlerinin bulunduğu bir yerleşim olmuş ve devamında çeşitli kamu kurumlarının oluşturduğu kamp alanlarına ev sahipliği yapmıştır.

Sayfiye mekânlarının kıyı, kırsal ve dağlık alanlar olmak üzere üç şekilde yerleşim göstermesine dayanarak Dragos’taki yerleşimin kıyı alanı şeklinde karşımıza çıktığı görülmektedir. İstanbul'da kentleşme etkilerinin yoğun olarak görülmeye başlaması insanların kıyılara yönelmesini sağlamış; bu sebeple kıyılar yerleşim ve dinlenme alanları olma açısından çekici bölgeler haline gelmiştir. Dragos semti, kıyı sayfiyelerinin gelişim şekilleri bağlamında değerlendirildiğinde ise, 1940'larda Ankara'nın önde gelen isimlerinin sayfiye yeri olarak kullanılmak üzere Dragos tepesinde kısmen planlı olarak kurduğu kooperatifi ve 1999 yılında bölgenin sit alanı ilan edilmesi ile planlı bir kıyı sayfiyesi olarak değerlendirilebilir. Ancak bunun yanında, 1970'lerde bölgede kamu kurumlarında çalışanların kişisel girişimleri ile başlatılan kamp yaşamının Dragos'u kendiliğinden gelişen bir kıyı yerleşimi haline gelmesini sağlamıştır. 1970 yılına ait hava fotoğrafları üzerinden Dragos incelendiğinde, 1970'li yıllarda hem ulaşım ağı, hem de plaj, kamp ve konutların yerleşimi açısından Lavery'nin (1974) bir kıyı yerleşimi için önerdiği mekân seçimlerinin hepsinin varolduğu görülmektedir (Fig. 9). 


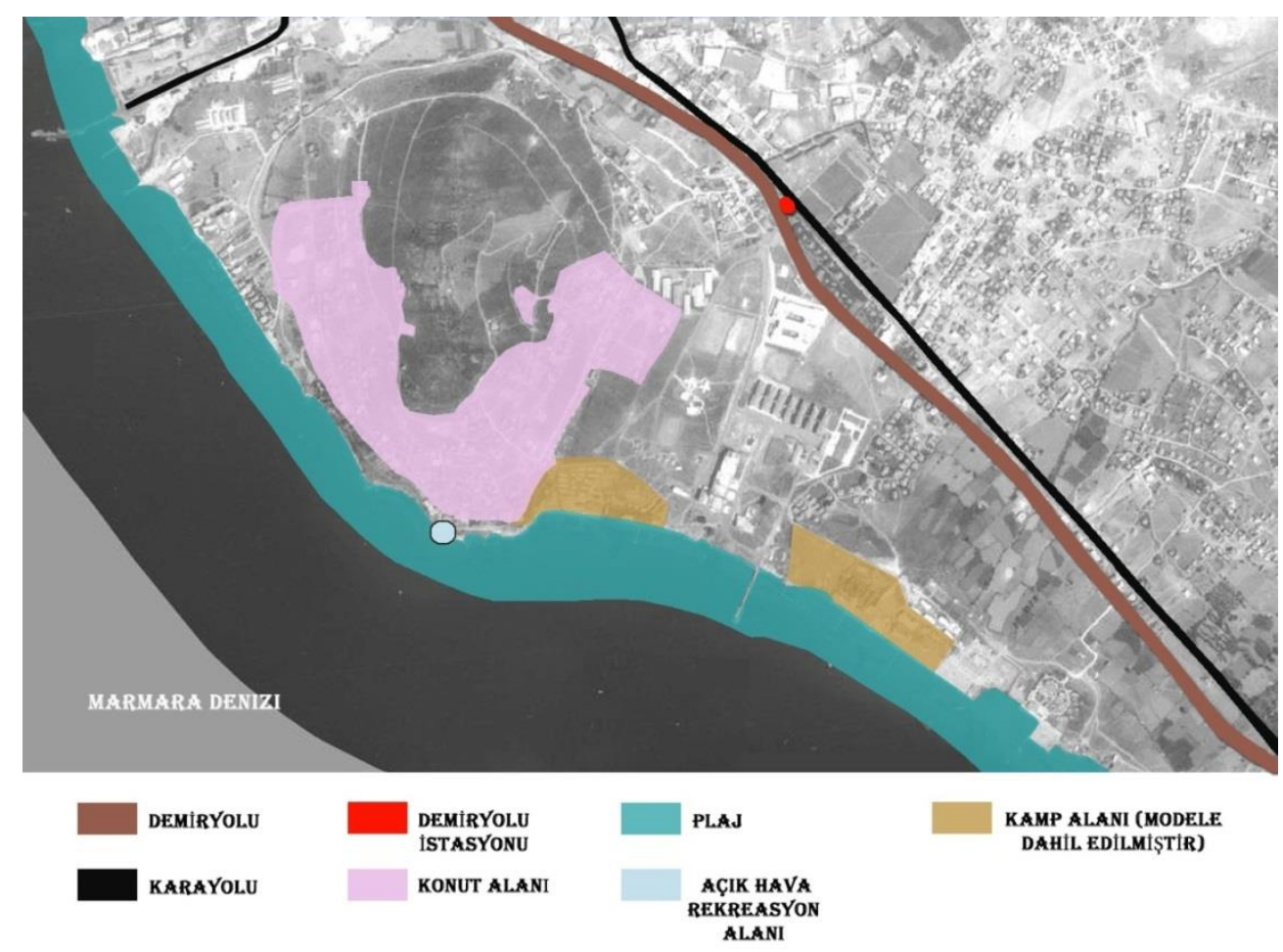

Fig. 9. Lavery (1974) Modeline Göre 1970 Yılında Dragos’taki Arazi Kullanım Biçimi, (yazar tarafından üretilmiştir, 2018)

Barret'in (1958) hazırladığı gelişme modeli Dragos üzerinden incelendiğinde; Özgüç'ün (1998) yorumunda belirttiği gibi kıyı alanlarına ticari ve yüksek katlı yapıların inşa edilmesi gibi bir kullanım şeklinin burada uygulanmadığı görülmektedir. Dragos yerleşiminde kıyı ile konut alanları arasında engel oluşturacak bir yapılaşmaya izin verilmemiş, yerleşim kurulduğu dönemdeki fiziki yapısını günümüze kadar taşıyabilmiştir. Ayrıca, modele göre yorumlanan konut alanları ile araç yolu arasında yayalar için olumsuz olarak görülebilecek bir durum da Dragos için söz konusu değildir. Modelde belirtilen ve 1970'lerde Dragos'taki kıyı eğlendirme faaliyetlerinin yapıldığı Orhantepe Deniz Kulübü 2000'li yıllarda kapanmış ve 2018 yılında denize uzaktan bakan, herkese açık özel bir işletme olarak kafeye dönüşmüş̧ür. Plajlar ise dolgu alanının altında kalmıştır. Dolgu alanı günümüzde bisiklet yolu, yürüyüş ve koşu alanlarının olduğu açık bir rekreasyon alanı şeklinde kullanılmaktadır. Belirli düzeyde ağaçlandırma ve bitkilendirme çalışması yapılmıştır (Fig. 10).

1968 yılında Dragos'un sahil kesiminde başlayan kamp yaşantısı, bölgenin kendiliğinden gelişmesini sağlayan önemli bir faktör olmuş; orta gelirli ailelerin yaz mevsimini geçirmek üzere Dragos'ta kamp yapması bölgeyi odak noktası haline getirmiştir. Dragos'ta plajların açılması, bölgenin Cevizli tren istasyonuna yakın olması ve kamp için gerekli ihtiyaçlardan en önemlisi tepeden doğal kaynak suyunun gelmesi burada kamp yapma fikrinin başlıca nedenleri olmuştur. Bölgenin kamp sakinleri ise PTT, DSİ, Tekel, Elektrik İşleri Etüd ve Hava Kuvvetleri kurumlarından meydana gelmektedir. Bu kurumlarda görev yapan kişiler yaz dönemi boyunca aileleri ile Dragos'ta tatil yapma imkânı bulmuşlardır. 


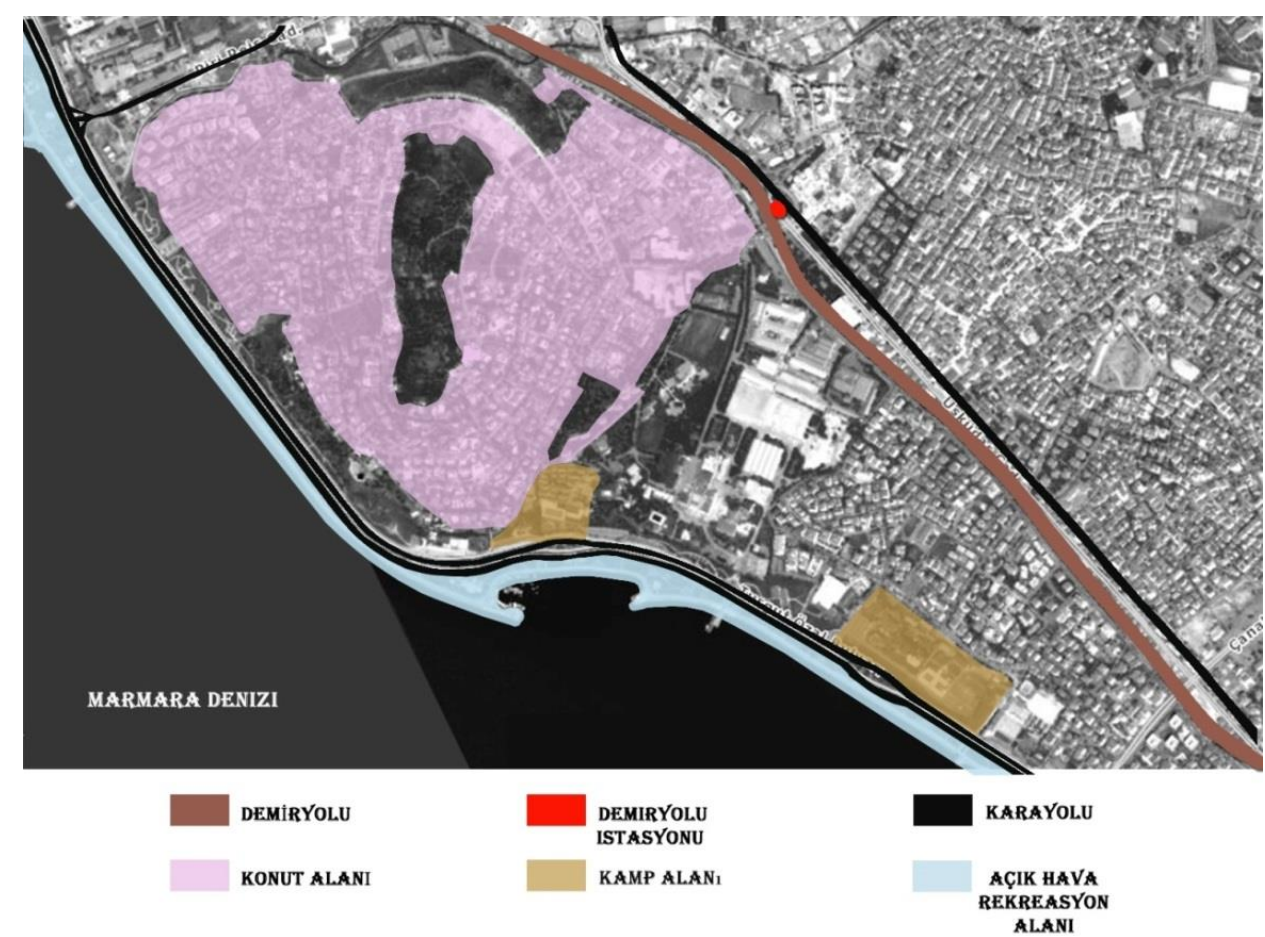

Fig. 10. Lavery (1974) Modeline Göre 2018 Yılında Dragos’taki Arazi Kullanım Biçimi (yazar tarafından üretilmiştir 2018)

Çevresinde tatil faaliyetlerinin bulunmaması, küçük ve seçkin bir yerleşim olması nedeni ile Dragos, Lavery'nin (1971) 8 tipte sınıflandırdığı sayfiye mekânlarından 'küçük sayfiyeler' grubunda yer edinmektedir. Bölgede her yıl yaz aylarında bir araya gelerek Dragos sahilinde sürdürülen kamp yaşantısını gelenek haline getiren kamu kurumları çalışanları ile yazlarını Dragos tepesindeki villalarında geçiren Ankaralı bakan ve milletvekilleri bölgenin küçük, seçkin bir sayfiye olarak gelişmesini sağlamıştır. Crofts'un yaptığı sınıflandırmaya dâhil edilen 'müstakil villalar' özellikle Ankaralı aileler tarafından ikinci konut şeklinde kullanılarak bölgedeki yerini alırken, kamu kurumları çalışanlarının çadırlı kamp yaşantısı Crofts'un (1977) ikinci konut olarak belirttiği 5 tip sayfiye mekânından biri olarak kıyı mekânının gelişiminde kendisine yer bulmuştur. Bu sinıflandırma; kamp dönemlerinde Dragos sahilinde ikinci konut olarak kullanılmak üzere kurulan kamplar, çadırlar ve Dragos tepesinde inşa edilmiş bahçeli, müstakil villa tipi konutlar ile açıklanabilir. Böylelikle bölgede farklı sosyo-ekonomik grupların aynı anda sayfiye yaşantısı sürdüğü de ortaya konmaktadır. Dragos'taki kamp döneminin yerleşim planı incelendiğinde (Fig. 11) yerleşimin sınırı 'Mor Kayalar Koyu' ile başlamakta ve Hava Kuvvetleri Kampı'na kadar uzanmaktadır. İsmini kayalarının mora yakın olmasından alan koy, o dönem tüm halkın kullanıma açıktır. Mor Kayalar'ın hemen yanında Orhantepe Deniz Kulübü ve iskelesi bulunmaktadır. Kulüp sadece Dragos tepesindeki villalarda yaşayan kişilerin üye olabildiği ve hizmet alabildiği bir yapıdır. Restoran, kafe, tenis kortu ve yan tarafında teknelerin bırakıldığı barınaktan meydana gelen yapı, kamp sakinlerinin de özendiği fakat faydalanamadığı bir mekân olmuştur. Deniz kulübünün yanında "Sarı Kayalar" olarak da anılan "Bedavacılar Plajı"' bulunmaktadır ve Mor Kayalar Koyu'nda olduğu gibi halkın kullanımına açıktır. Bedavacılar Plajı'nın devamında ise sırası ile PTT Kampı, DSİ Kampı ve Tekel Kampı yer almaktadır, Tekel arazisinin bittiği sınırdan itibaren Kum Plaj, Elektrik İşleri Etüd Kampı ve Hava Kuvvetleri Kampı bulunmaktadır (Çetin 2017). 
1970 yılına ait harita üzerinden bölgenin geneli değerlendirildiğinde, kamp alanlarının yanı sıra Kartal'ın önde gelen sanayi yapılarının (Sigara Fabrikası, Mutlu Akü Fabrikası ve Yunus Çimento Fabrikası) konumları da görülmektedir (Fig. 11). Uzun yıllar bu bölgede hizmet veren ve bölgenin gelişimi açısından önemli bir yere sahip olan sanayi yapıları, 1980'lerden sonra şehrin uzak bölgelerine taşınmışlardır.

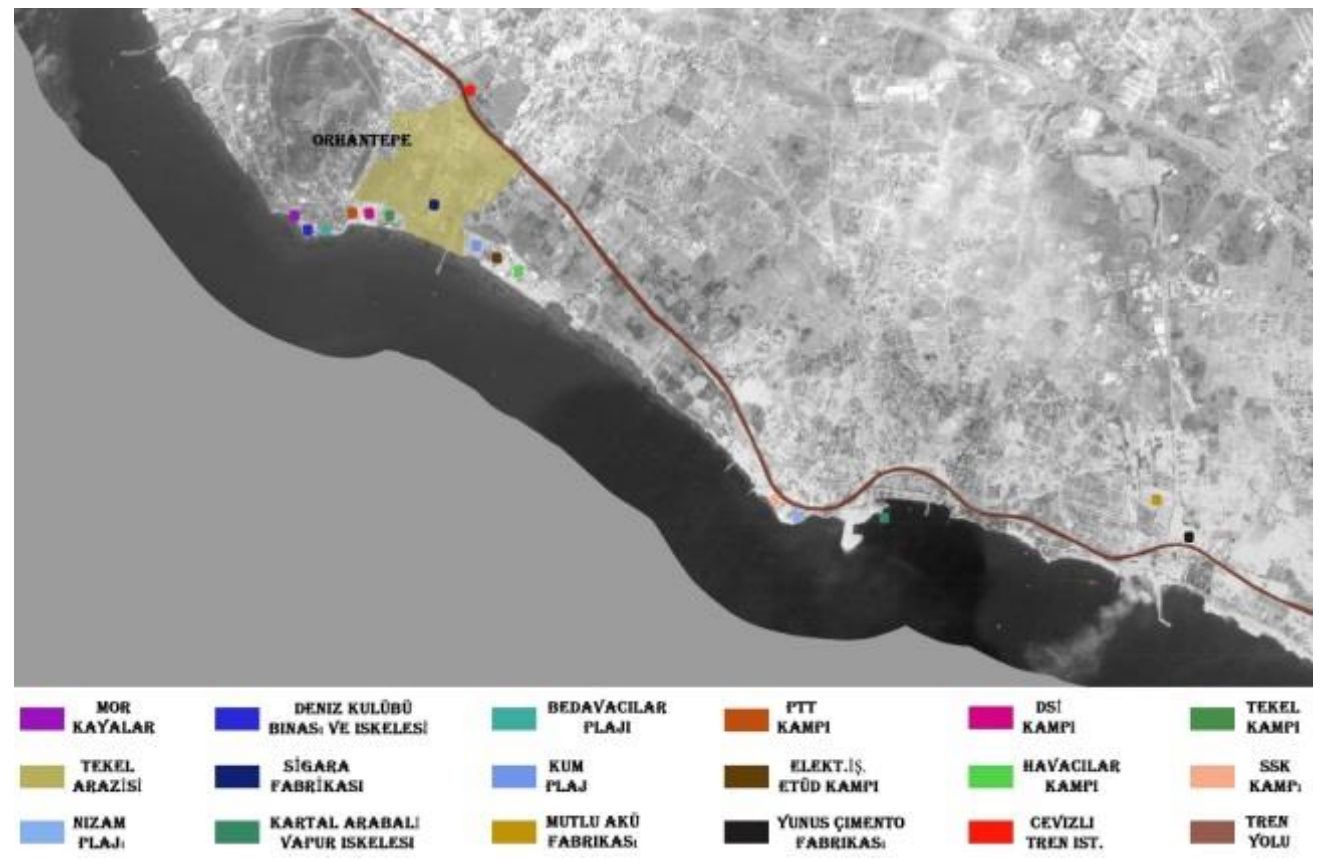

Fig. 11. Dragos ve Yakın Çevresi, 1970 (yazar tarafından üretilmiştir 2018)

Dragos'un bir kıyı sayfiyesi olarak değişimi 1970, 1982, 2006 ve 2018 yıllarına ait hava fotoğrafları üzerinden incelenecektir. Bu hava fotoğraflarında sayfiye yaşantısını oluşturan ulaşım ağı, kamp alanları ve konut alanları belirtilmiştir.

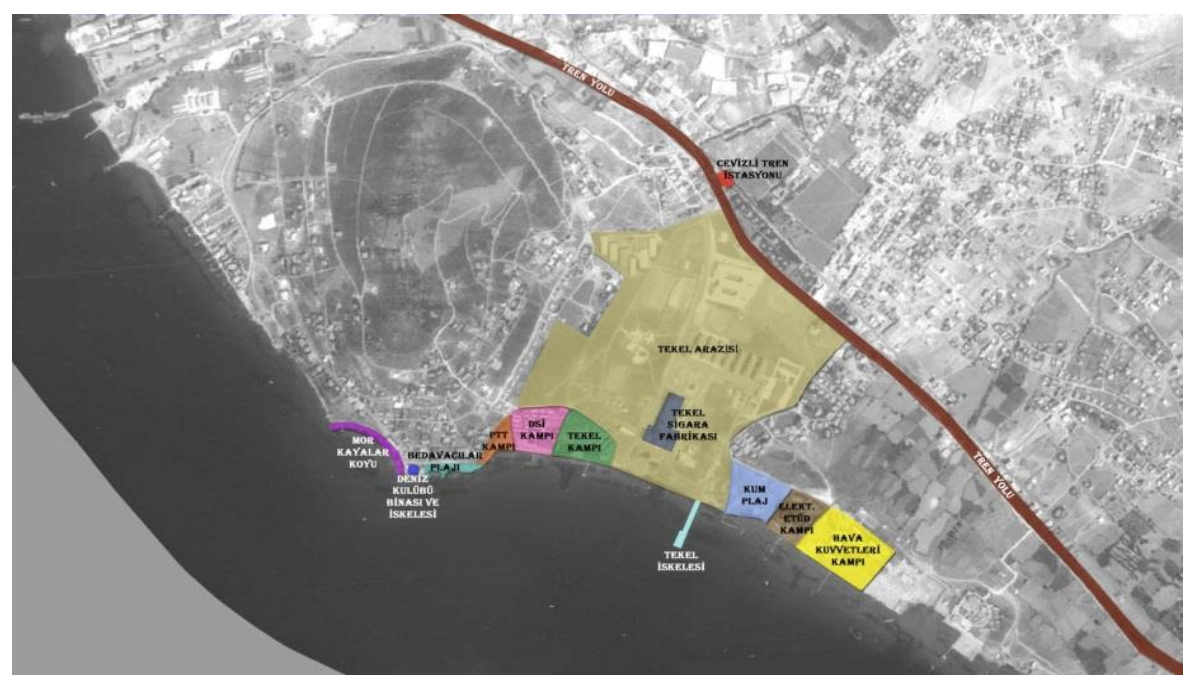

Fig. 12. Dragos'ta Kamp Yerleşim Alanları, 1970 (yazar tarafından üretilmiştir 2018) 


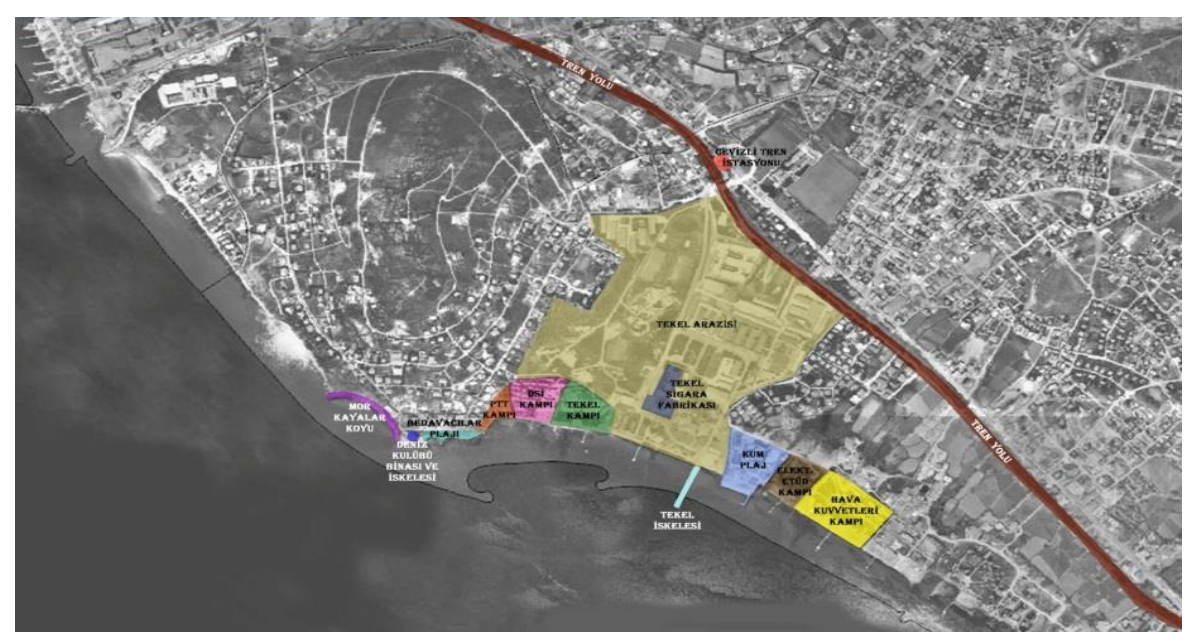

Fig. 13. Dragos'ta Kamp Yerleşim Alanları, 1982 (yazar tarafından üretilmiştir 2018)

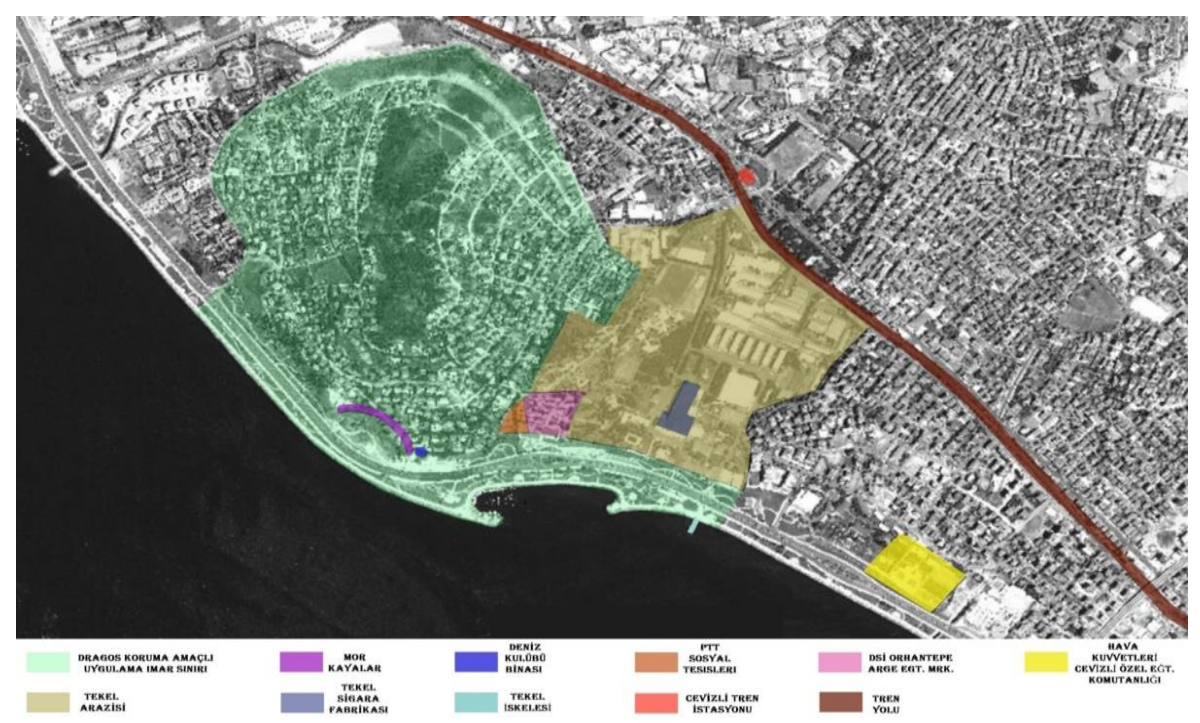

Fig. 14. Dragos’ta Kamp Yerleşim Alanları, 2006 (yazar tarafından üretilmiştir 2018)

1982 yılına gelindiğinde kamp faaliyeti aktif olarak yapılmasa da mevcut alanların hala varolduğu görülmekte; PTT, DSİ ve Hava Kuvvetleri kurumlarının kamp hizmeti devam etmektedir. Ayrıca bölgedeki yapılaşmanın yoğunlaştığı anlaşılmaktadır (Fig. 13).

2006 yılına gelindiğinde, 2003 yılında ilan edilen Dragos Koruma Amaçlı Uygulama İmar planının sınırları belirlenmiştir. Plajlar ve kampların bir bölümü tamamen yok olmuş; PTT kamp1 sosyal tesise, DSİ kamp1 eğitim merkezine dönüşmüştür. Hava Kuvvetleri yaz aylarında kamp hizmetini sürdürmektedir. Sigara fabrikası kullanılmayan bir durumdadır (Fig. 14).

2018 yılında ise, Orhantepe Deniz Kulübü mevcut değildir. Bölgenin tarihi yapılarından biri olan sigara fabrikası ve Tekel arazisi artık üniversite kampüsü olarak kullanılmaktadır. DSİ, eğitim merkezi olarak işlevini sürdürürken, PTT sosyal tesisleri de eğitim merkezi olarak hizmet vermeye başlamıştır (Fig. 15).

Dragos'taki mekânsal gelişimin fiziksel yönden incelenmesinin yanında sosyal yönden de incelenmesi hedefi doğrultusunda, kullanıcılar ile görüşmeler gerçekleştirilmiştir. Kullanıcılara psikocoğrafik bakış açısı ile yöneltilen sorulardan oluşan bu görüşmeler sayesinde Dragos'u anlatan verilere ulaşılmaya çalışılmıştır. 1960-2018 tarihleri arasında sürekli veya geçici olarak Dragos'ta yaşamış veya çalışmış kullanıcılarla, Ekim 2017 ile Nisan 2018 tarihleri arasında 
yüzyüze görüşmeler gerçekleştirilmiştir. Bu görüşmeler 1şığında Dragos'taki kamplardaki yaşantı bu bölümde detaylı olarak açıklanmaya çalışılacaktır.

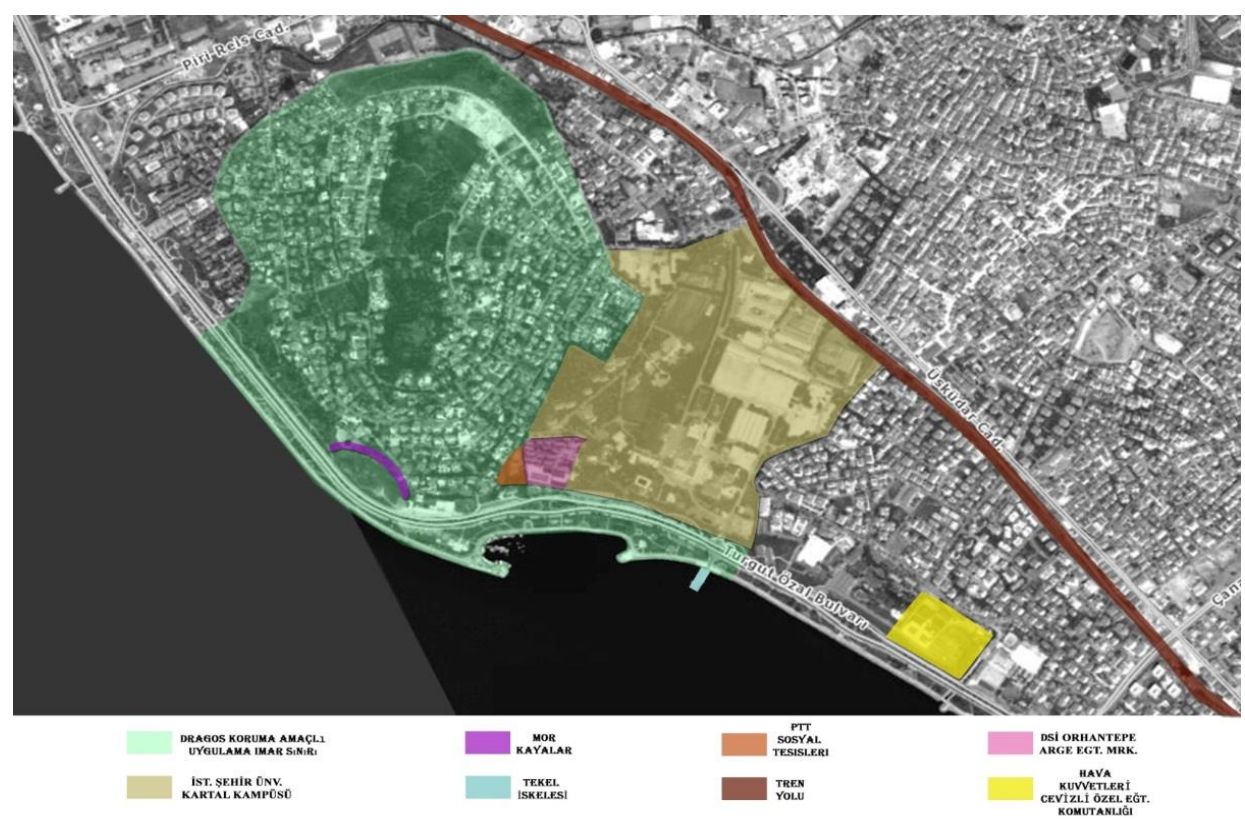

Fig. 15. Dragos’ta Kamp Yerleşim Alanları, 2018 (yazar tarafından üretilmiştir 2018)

PTT Kampı, Dragos Kablobaşı'ndaki arazinin PTT'ye ait olması ile başlamıştır. Kablobaşı, ters çapa şeklinde bir kulübedir ve Büyükada' ya giden telefon kablolarının denizaltına girdiği yerdir. Dik bir eğimle deniz kıyısına ulaşıldığı noktada bulunan Kablobaşı, kamp yapılacak arazinin bulunduğu yerdir. Çadırların kurulması ile ilk adım atılmış, kalan ihtiyaçlar el birliği ile tamamlanmıştır. PTT Müdürlügü'nün desteği sayesinde, eski telefon direkleri ve PTT'nin anlaşmalı olduğu Netaş firmasından gelen kontraplaklar ile mutfak, gazino, wc ve kampın güvenliği açısından yolun başına bekçi kulübesi yapılmıştır (Fig. 16) (Çetin 2017).

“......Illk iki sene, 1968-1969'da elektriğimiz yoktu. Gaz lambası kullanırdık, şanslı olanlarda da lüx lambası vardı. Biz kamp olarak 1970'te aldık elektriği. Suyu da zaten tepeden gelen kaynak suyundan kullaniyorduk. Öncelikle tabi bir gazino yapmak gerekti, kapalı bir yer. Çünkü çadırlara sadece yatmaya gidiliyordu. Yemek yemek için ya da sosyal buluşmalar için gazino kullanılırdl. Biraz sefil fakat tatlı bir kamp yaşamı oldu (Fig 17). Yaşamımın en güzel yılları... Okul kapanıyor, bütün çocuklar orada buluşuyoruz, anneler yemek yapıyor. Gün nasıl geçiyor anlamıyoruz......” (Çetin, 2017). “......Sonra, DSİ kamp bitim balosu düzenlerdi. Biz de baloya katılırdlk ve orkestra gelirdi. Tabi nereye orkestra gelirse bütün Dragos sahili inlerdi. Balo gecelerinde en güzel giysilerimizi giyer, gider orada dans ederdik. Sonradan diğer kamplarda da balo geceleri düzenlenmeye başlamışt ......" (Çetin, 2017).

1975 yılında çadır kamp döneminin sona ermesi ile 1983 yılında Dragos Kablobaşı'ndaki araziye PTT tesisleri inşa edilmiştir. Tesis 1983-1990 yılları arasında PTT mensuplarına kamp hizmeti vermeye devam etmiştir. Konaklama, restoran ve yönetim birimlerinden meydana gelen tesis, bu yıllar arasında yılboyu kesintisiz faaliyetlerini sürdürmüştür. 1990-1998 yılları arasında PTT sosyal tesisleri olarak kullanılmıştır (Fig. 18) (Derin 2017). 


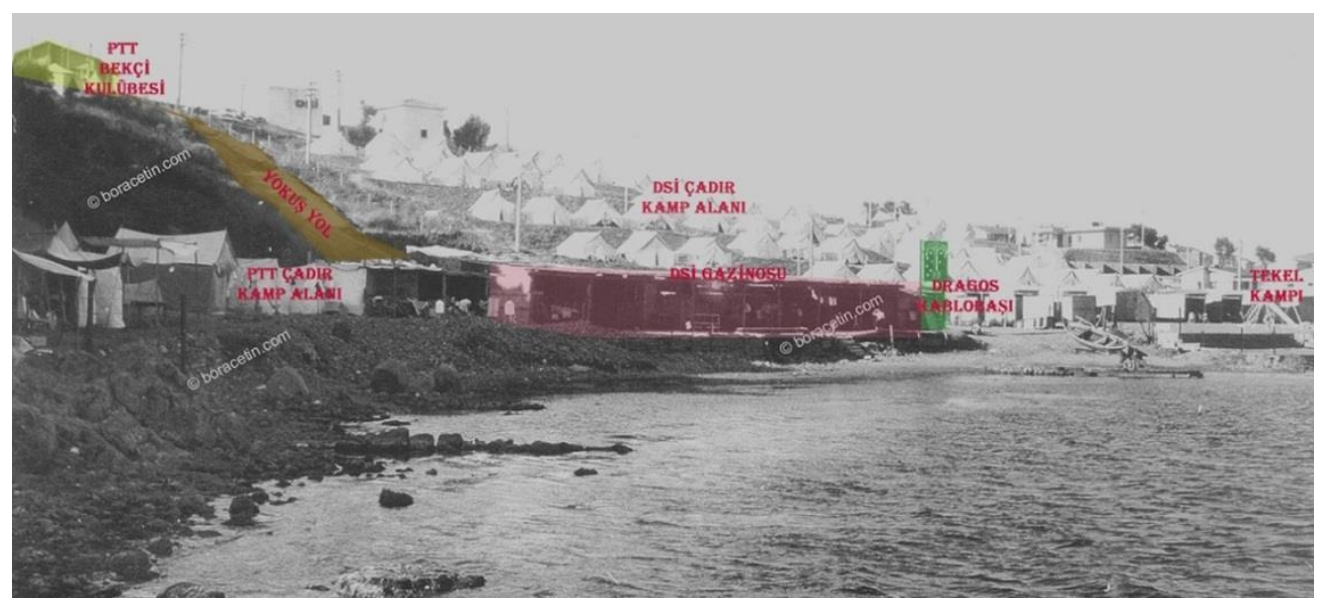

Fig. 16. Dragos Kampı, 1968 (URL7) (yazar tarafından belirlenmiştir 2018)

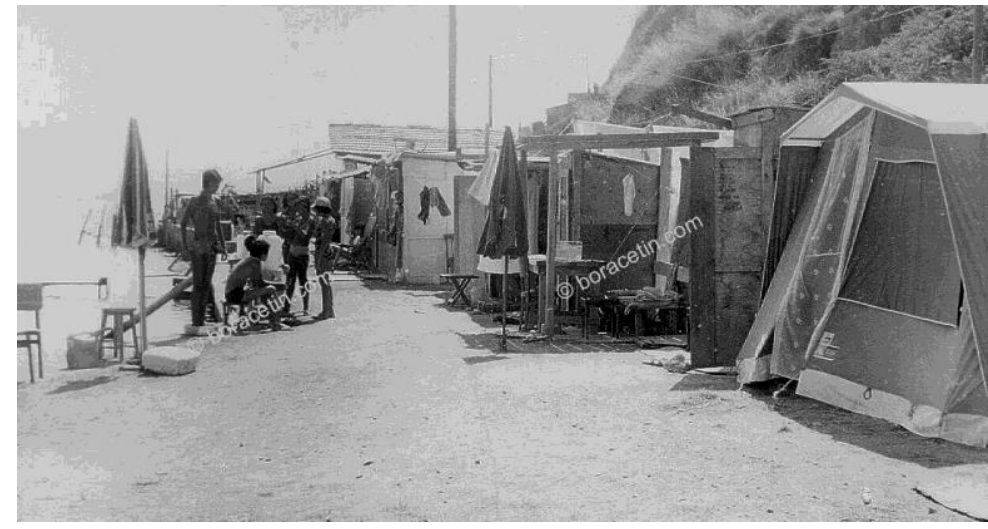

Fig. 17. PTT Kamp1, 1968 (URL7)

2015 yılına gelindiğinde PTT sosyal tesisleri, planlanan yeni işlevi ile İstanbul Anadolu yakası PTT Başmüdürlüğü Yapı ve Teknik İşler Müdürlüğü tarafından hazırlanan uygulama projeleri doğrultusunda eğitim merkezi olarak kullanılmak üzere, bölgenin gelişimine uygun bir şekilde korunarak yenilenmiştir (Fig. 19) (Derin 2017).

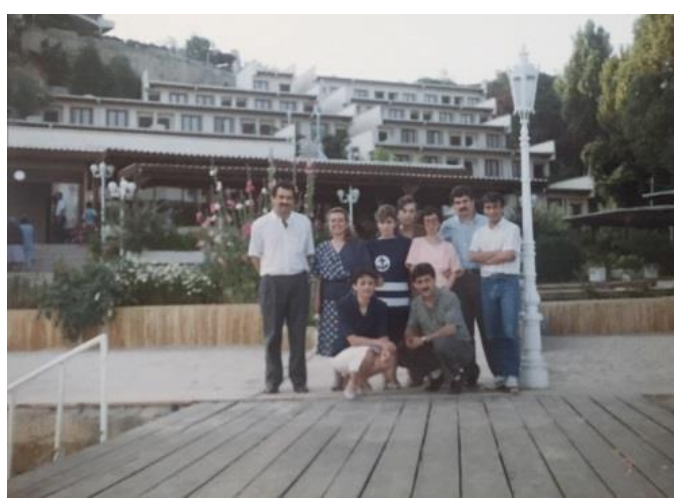

Fig. 18. PTT Tesisleri ve İskelesi, 1980 (Derin 1980

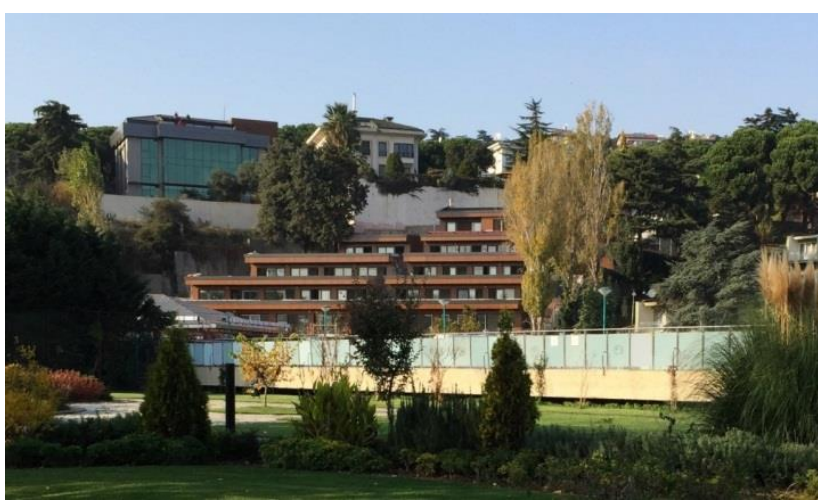

Fig. 19. PTT Eğitim Merkezi (yazar tarafından fotoğraflanmıştır 2018)

2017 yılının sonunda revizyon projesi tamamlanan tesis, 2018 yılının ocak ayından itibaren PTT'nin çalışanlarına eğitim verdiği, toplantı, seminer ve çeşitli organizasyonların gerçekleştirildiği bir yapı olarak kullanılmaya başlamıştır. Günümüz koşullarına göre yenilenen yapılar 
farklı bir görünüm kazanmıştır. Yapı malzemelerinin oldukça geliştiği bu dönemde tercih edilen giydirme cephe, 1sı yalıtımlı alüminyum doğramalar, çelik merdiven, fotoselli otomatik sürme kapılar, asma tavan uygulamaları, sürme cam sistemleri, hareketli bölme duvarlar ve çelik çatı kullanımı ile yapılara yeni bir yorum getirilmiştir. Bulunduğu yerleşim alanının özellikleri bakımından aynı zamanda rekreasyon amacı ile kullanılabilmektedir.

DSİ Kampı, PTT ile komşu olan DSİ kampı, 1968 yılında çadır ve ahşap barakalar ile başlamıştır. 1969 yılında DSİ 14. Bölge Müdürlüğü tarafından Dragos'taki araziye lojman binaları inşa edilmiştir (Öztürk 2018).

“......Çadırları hep biz kurardık, 35 tane çadır vardı. 4-5 tanesi ahşap barakaydl. Üst düzeydeki kişiler ahşap barakalarda kalırdı. Derme çatma bir de gazinomuz vardl. Motorumuz her gün saat 10.00 - 13.00 arasl adalara servis yapardl. Sonra, kamp büyük motor kiralardı ve sık sık boğaz gezileri düzenlenirdi. Bizim yan tarafimızda PTT Kampı bulunuyordu. Dönem olarak PTT ile DSI hemen hemen aynıdır fakat bizim DSI biraz daha eski. Diğer yanımızda da Tekel Kampı'nin barakaları vard ......" (Fig. 20) (Öztürk 2018).

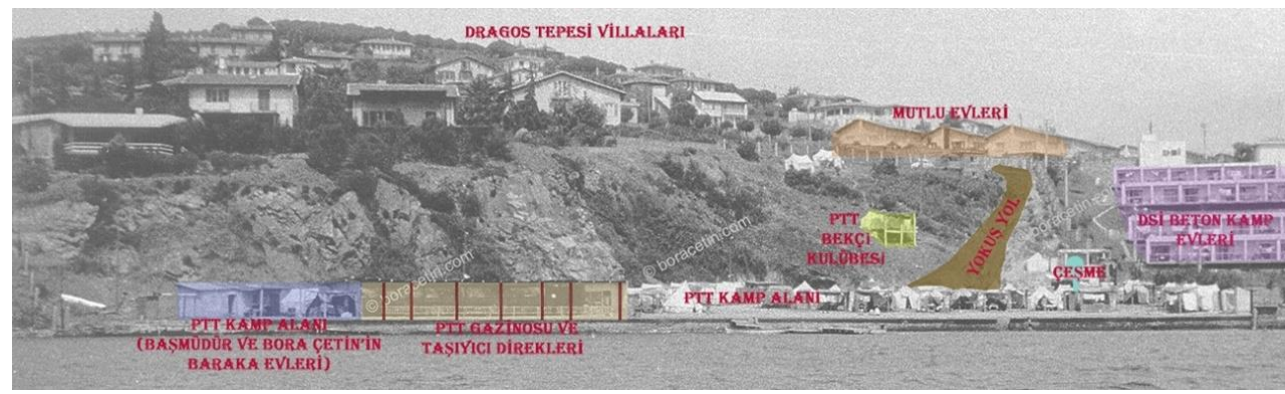

Fig. 20. Dragos Kamp1, 1970 (URL7) (yazar tarafından belirlenmiştir 2018)

Lojmanlar o yıllarda DSİ mensuplarına kamp hizmeti sunmuş, 2005 yılında revize edilerek DSİ ar-ge eğitim merkezi olarak kullanılmaya başlamış ve günümüzde de işlevini sürdürmektedir (DSİ 2017).

14 adet parselden oluşan ve toplam $17.811 \mathrm{~m}^{2}$ lik alan üzerinde bulunan tesis, faaliyetleri açısından fonksiyonunu yitirmesi ve atıl vaziyette olma gerekçesi ile 2005 yılında onarıma alınmıştır. Bölgenin topoğrafik yapısı, iklim şartları ve mevcut mimari dikkate alınmış, İstanbul 14. Bölge Müdürlüğ̈̈ tarafından öngörülen proje kapsamında, ulusal ve uluslararası eğitim bilim merkezi, konaklama, spor tesisleri ve rekreasyon alanları planlanmıştır (Fig. 21, 22).

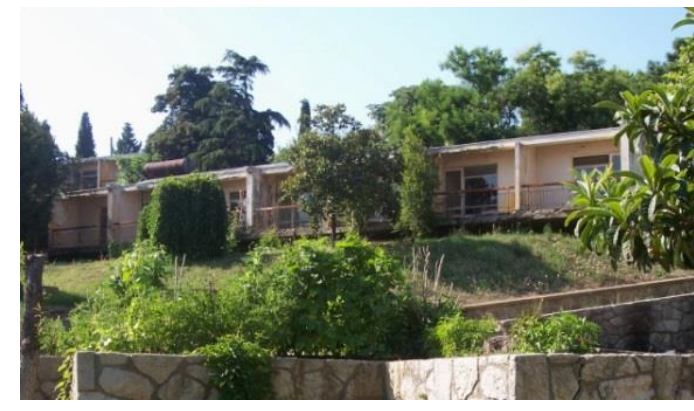

Fig. 21. DSİ Lojmanları (DSİ 2005)

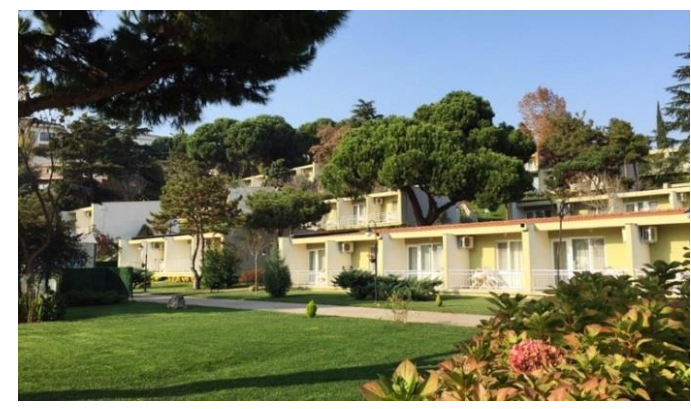

Fig. 22. DSİ Lojmanları (yazar tarafindan fotoğraflanmıştır 2018)

Lojman yapılarının revizyon öncesindeki sade görünümü, düz çatıları, dış mekan ile ilişkisi, geniş balkon ve pencereleri Cumhuriyet dönemine ait olduğunu hissettirmektedir. 2005 y1lında 
yenilenen yapılarda aslına uygun bir biçimde onarım gerçekleştirilmiş, 1960'lar dönemine ait modern mimarisinin korunması ile doğru bir uygulama yoluna gidilmiştir.

Tekel Kampt, DSİ'nin yanında yer alan Tekel kampı, PTT ve DSİ ile aynı dönemlerde kurulmuştur. 1970'lerde fabrika çalışanları tarafından yapılmaya başlamış, 1975 yılına kadar devam etmiştir. Gazino, iskele ve çadırlardan oluşan kamp alanında sınırlı imkânlar ile sürdürülen yaz kampları, sakinlerine unutulmaz günler yaşatmıştır (Fig. 23, 24) (Öztürk 2018).

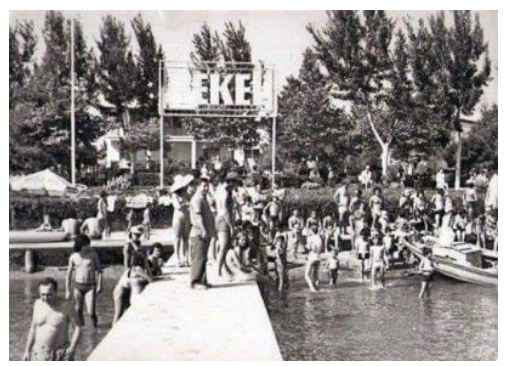

Fig. 23. Tekel Kamp1 1970’ler (URL8)

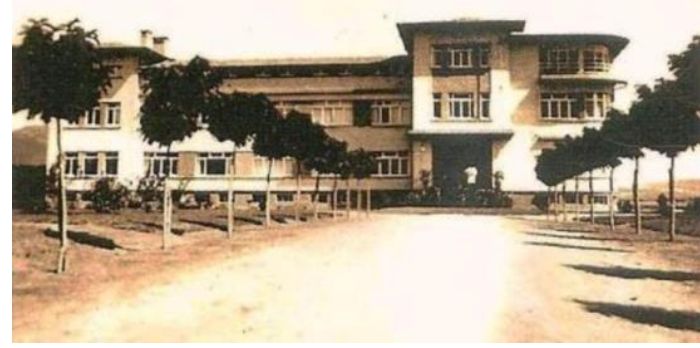

Fig. 24. Tütün Araştırma Enstitüsü (URL9)

Bu noktada kamp hikâyesinin temelini oluşturan Tekel'in tarihine değinmek faydalı olacaktır. Bölgenin tütün ile tanışması Osmanlı döneminde başlamış ve uzun yıllar devam etmiştir. Osmanlı döneminden beri bu bölgede Dramalı göçmenler tarafından tütün yetiştirilmesi üzerine, 1931 yılında tütün deneme evi yapılmış ve 1935 yılına kadar Türkiye'deki Tütün Deneme evlerini kurumsal bir yapıya dönüştürmek amacı ile de Tütün Araştırma Enstitüsü inşa edilmiştir. Enstitüde tütün eksperleri eğitilmiş, örnek tütünler üretilmiş ve tütün analizleri yapılmıştır. O yıllarda enstitü ile İstanbul arasındaki ulaşımın rahat sağlanabilmesi için enstitünün önüne tren istasyonu kurulmuş ve bölgenin gelişimi açısından önemli bir öğe olan Cevizli tren istasyonu bu sayede ortaya çıkmıştır (URL9).

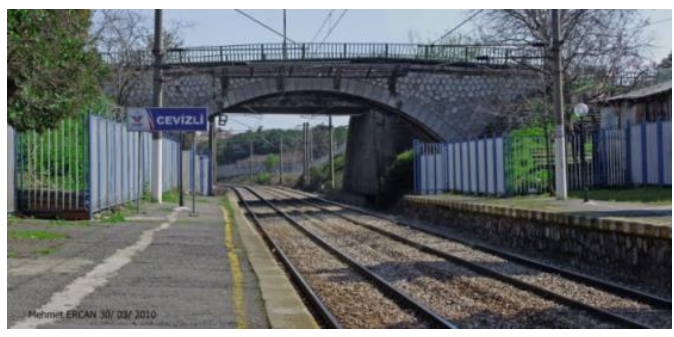

Fig. 25. Cevizli Tren İstasyonu (URL10)

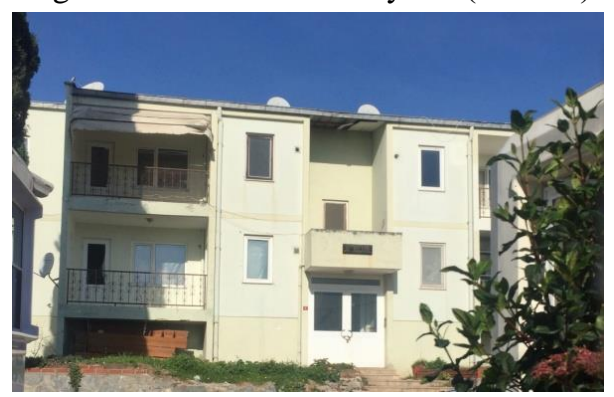

Fig. 27. Tekel Lojmanları (yazar tarafından fotoğraflanmıştır 2018)

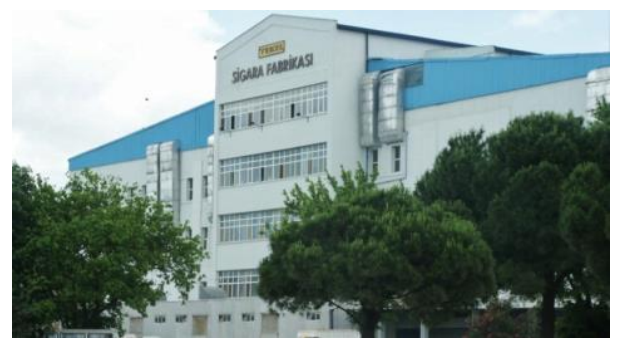

Fig. 26. Tekel Sigara Fabrikası (URL11)

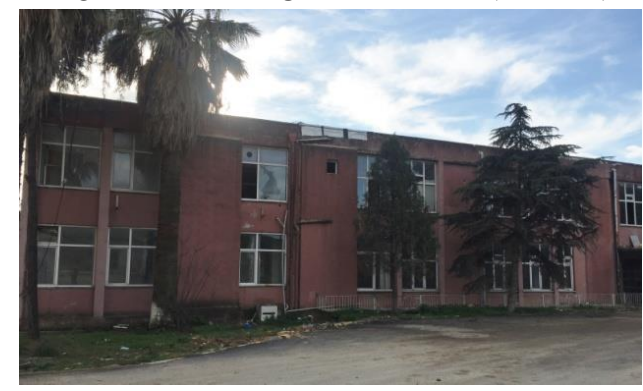

Fig. 28. Tekel Genel Müdürlük Binası (yazar tarafından fotoğraflanmıştır 2018) 


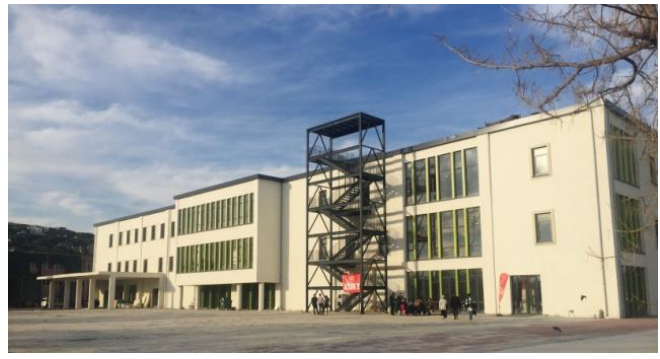

Fig. 29. Öğrenci Merkezi

(yazar tarafından fotoğraflanmıştır 2018)

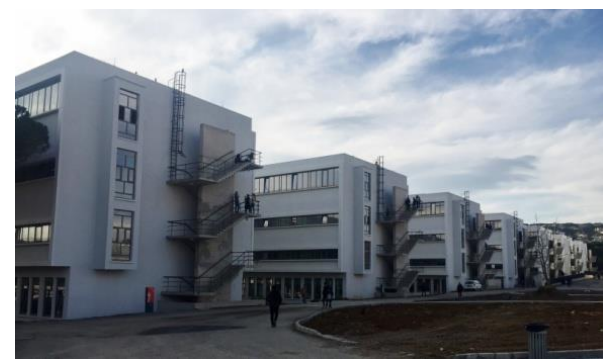

Fig. 30. Fakülte Binaları (yazar tarafından fotoğraflanmıştır 2018)

II. Dünya Savaşı'ndan sonra sigara fabrikalarının yetersizliği üzerine 1946-1948 yılları arasında fabrika binasının yapımı için çalışmalar başlamış, Amerikalı bir firma tarafından projeler hazırlanmıştır. İnşası 1957 yılında başlayan sigara fabrikası 1967 yılında açılmıştır. Bölgedeki eski ve önemli sanayi yapılarından biri olan Tekel sigara fabrikasında çalışan işçiler Cevizli Mahallesi'ni meydana getirmişlerdir (URL9). Tekel arazisinde fabrikanın yanı sıra tütün depoları, yönetim binası, lojman, konukevi, sosyal tesis ve futbol-basketbol sahaları bulunmaktaydı. Sigara, ambalaj, puro olmak üzere 3 bölümden meydana gelen Tekel 1980'lere kadar önemli bir gelir kaynağı olmuş, 1980 yılından sonra kapatılmıştır (Fig. 26, 27, 28) (Derin 2017).

Fabrikanın kapatılmasının ardından uzun yıllar boş kalan tesis, 2009 yılında üniversite kampüsü olarak işlevlendirilmeye başlanmıştır. Üniversite projesi kapsamında Tekel Fabrikası'ndan kalan tarihi yapıların bir kısmı yıkılıp yeniden inşa edilmiş, bir kısmı ise korunmuş ve müze olarak kullanılması amaçlanmıştır. Sigara Fabrikası yıkılıp yeniden inşa edilerek üniversitenin öğrenci merkezi olarak kullanılırken, Tekel Genel Müdürlük binası teknoloji ve transfer ofisi olarak değerlendirilmiş, Tekel sosyal tesis binası inşaat ve mimarlık ofisine dönüştürülmüştür (Fig. 29, Fig. 30). Tekel'in depo olarak kullandığ yapılar ise günümüzde rektörlük binası olarak hizmet vermektedir (Ertem 2017).

Elektrik İşleri Etüd Kampı, 1970'li y1lların yaz döneminde Dragos sahilinde yerini alan kurumlardan biri de Elektrik İşleri Etüd İdaresi olmuştur. Diğer kamu kuruluşları gibi Elektrik İşleri Etüd Kampı da 1975 yılında son bulmuştur. 1976 yılında Dragos'taki tüm kamp sakinleri Kartal'da 'Mokamp' denilen bir kamp arazisine gitmiş, kamp yaşantısını bir ya da iki yıl orada sürdürmüşlerdir (Çetin 2017).

Elektrik İşleri Etüd İdaresinin kamp yaptığı Dragos'taki araziye 1997 yılında Maltepe Üniversitesi Meslek Yüksekokulu kurulmuş ve yaklaşık 10 yıl boyunca burada eğitim vermiştir. Üniversitenin kapatılması ile 2017 yılında yapının yeni işlevi olan hastaneye dönüştürülmesi için çalışmalar başlatılmıştır.

Hava Kuvvetleri Kampı, 1970'lerden beri kamp geleneğini sürdüren Hava Kuvvetleri, Cevizli Özel Eğitim Merkez Komutanlığı yerleşkesinde bulunmaktadır. Yıl içinde orduevi olarak kullanılan tesis, yaz aylarında kamp hizmeti vermektedir.

\section{Sonuç}

Yaz mevsimini geçirmek amacı ile gidilen sayfiye mekânlarının zamanla keşfedilmesi ve sayılarının hızla artması, sayfiye kültürünün ortaya çıkmasını sağlamıştır. Turizm, rekreasyon, ulaşım ve konut alanlarından meydana gelen sayfiye mekânları, insanların yaz mevsiminde yoğun olarak rağbet ettiği yerleşimlerdir. İstanbul'da sayfiye kültürü ve mekânı 1980'lerden sonra varlığını yitirmiş olsa da, Adalar ve Dragos yerleşiminde etkisinin hala devam ettiği görülmektedir. 1940'lı yıllarda sayfiye mekânı olarak gelişmeye başlayan Dragos, kent içinde seçkin bir kıyı yerleşimidir. İstanbul'da sayfiye kültürünün yaşandığı yerleşimlerden biri olarak uzun yıllar bu geleneğe ev sahipliği yapmıştır. 
Dragos semti, kıyı sayfiyelerinin gelişim şekilleri bağlamında değerlendirildiğinde ise, 1940'larda Ankara'nın önde gelen isimlerinin sayfiye yeri olarak kullanılmak üzere Dragos tepesinde kısmen planlı olarak kurduğu kooperatifi ve 1999 yılında bölgenin sit alanı ilan edilmesi ile planlı bir kıyı sayfiyesi olarak değerlendirilebilir. Ancak bunun yanında, 1970'lerde bölgede kamu kurumlarında çalışanların kişisel girişimleri ile başlatılan kamp yaşamı, Dragos'un kendiliğinden gelişen bir kıyı yerleşimi haline gelmesini sağlamıştır. Yerleşimin dikkat çekmesinde ve gelişmesinde, kamu kurumlarının meydana getirdiği bu kamp alanları oldukça önemli bir faktördür. Çadır kamp alanlarında başlayan bu gelenek, ilerleyen yıllarda kurumların müdürlükleri tarafından inşa edilen betonarme yapıdaki tesislerde eğitim ve sosyal faaliyetler olarak sürdürülmektedir. Yaz dönemlerinde sayfiye amaçlı kullanılan semt, inşa edilen sahil yolunun semtin denizle olan ilişkisini kesmesi üzerine ve kentte yaşanan diğer hızlı değişimlere paralel olarak zaman içerisinde bu özelliğini yitirmeye başlamıştır. Fakat tesislerin yaz aylarında sunduğu kamp hizmetinin devam etmesi, yerleşimin sayfiye ruhunu halâ kaybetmediğini göstermektedir.

Uzun yıllar kentteki sayfiye geleneğine tanıklık eden Dragos Tepesi ve Yakın Çevresi, Kültür ve Tabiat Varlıklarını Koruma Kurulu'nun kararı ile koruma altına alınmış, böylece özel bir yerleşim alanı olduğu tescillenmiş̧ir. Koruma amaçlı uygulama imar planında belirlenen sinırlar, mevcut donatı alanları ve plan notları esas alınarak uygulama yapılabilmektedir. Her ne kadar koruma planı yerleşimdeki konutların varlığını koruma altına almasa da, yerleşimin yeşil dokusunu ve ayrık düzen villa tipi konut dokusunu korumaktadır. Bu sebeple, Dragos tepesi Türkiye'nin villa tipi konut tipolojisi için bir açıkhava müzesi niteliğindedir. Kent içinde yeşil kalabilen sayfiye yerleşimi görünümündeki semtlerden biri olan Dragos'un halen sürdürmekte olduğu sayfiye yaşantısı, doğal ve kültürel mekân özellikleri ile İstanbul Anadolu yakasının önemli semtlerinden biri olduğunu söylemek mümkündür.

\section{Yazarın Notu}

Bu çalışma; 2018 yılında, Yeditepe Üniversitesi Fen Bilimleri Enstitüsü'nde Dr. Öğr. Üyesi Zeynep Yazıcıŏ̆lu Halu danışmanlığında tamamlanmış olan "Sayfiye Yerleşimlerinde Villa Tipi Konut Gelişiminin Incelenmesi: Dragos, Orhantepe Mahallesi Örneği'” başlıklı yüksek lisans tezi esas alınarak hazırlanmıştır. 


\section{KAYNAKÇA}

Aksel A. (1994). “'Kartal”. Dünden Bugüne İstanbul Ansiklopedisi (Cilt 4) 471-473. İstanbul 1994. Anonim (1994). “'Dragos”. Dünden Bugüne İstanbul Ansiklopedisi (Cilt 3) 103. İstanbul 1994.

Anonim (2005, Aralık 1). "'Orhantepe'. Kartal Kentim Gazetesi.

Anonim (2009). “'Dragos Doğayı Koruma Derneği’”. Kadıköy Life 28/5 (1990).

Atik M., Altan T. \& Artar M. (2006). "Turizm ve Doğa Koruma "Güney Antalya Bölgesi": Gelişmeler ve Sonuçları’'. Akdeniz Üniversitesi Ziraat Fak. Dergisi 2 (2006). 165-177.

Barrett, J. A. (1958). The seaside resort towns of England and Wales. Ph.D. Thesis. University of London, UK 1958.

Bora A. (2014). "Sayfiyedeki Gibi Serazat”, Ed. Tanıl Bora. Sayfiye Hafiflik Hayali (2014) 7-12. İstanbul.

Crofts R. (1977). “'Caravans and Second Homes: Rural Planning Problems in Argyll’. Symposium on Second Homes (1977).

Doğaner S. (1991). “Dağ Turizmine Coğrafi Bir Yaklaşım: Uludağ'da Turizm’’. Atatürk Kültür, Dil ve Tarih Yüksek Kurumu Coğrafya Bilim Ve Uygulama Kolu Coğrafya Araştırmaları Dergisi 3/3 (1989) 137-154.

Gökdeniz A. (2009). Türkiye'de İkinci Konutların Turizme Kazandırılması ve Ayvalıkta İkinci Konutlar Üzerinde Yapılan Araştırma Işı̆̆ında Uygulanabilir Bir Model Önerisi. M. Kemal Dedeman Yarına Bir Değer Bırak Proje Yarışması Turizm Sektörü Üçüncülük Ödülü. İstanbul 2009.

Klemm M. (1996). 'Languedoc Roussillon: Adapting the Strategy'. Tourism Management 17/2 (1996) 133-139.

Koday S. (2000). “Haydarpaşa-Gebze Arasındaki Demiryolu Banliyö Ulaşımı’. Türk Coğrafya Dergisi 35 (2000) 261-276.

Lavery P. (1974). "Resort and Recreation”. Ed. Patrick Lavery. Recreational Geography (1974) 167-196. New York.

Mercer D. (1960). "Urban Recreational Hinterlands: A Review and Example'. The Professional Geographer. 22/2 (1960) 74-78.

Özgüç N. (1977). “'Sayfiye Yerleşmeleri: Gelişme ve Başlıca Özellikleri’. İstanbul Üniversitesi Coğrafya Enstitüsü Dergisi 22 (1977) 143-162.

Özgüç N. (1996). Turizm Coğrafyast. İstanbul 1996.

Özgüç N. (1998). Turizm Coğrafyası. İstanbul 1998.

TMMOB. (2009). Türkiye’de Mimarlık. Ankara 2009.

Yağan N. B. \& Binan C. Ş. (2017). "İstanbul'un Tarihi Sayfiye Alanlarındaki Yapıların Komşuluk İlişkileri Üzerine Bir Değerlendirme’’. Trakya Üniversitesi 10. Uluslararası Sinan Sempozyumu (27-28 Nisan 2017). Cilt 1 (2017) 129-138.

Yazıcıŏ̆lu Z. (2001). 1950-1970'lerde İstanbul'da Konut Mimarisi: Băgdat Caddesi Örneği. Yüksek Lisans Tezi. İTÜ, İstanbul 2001.

\section{İnternet Kaynakları}

Url 1, http://www.mahallemistanbul.com/MahallemSEGE_/?i=2\&v=2\&t=2016\&r=1 1 Mart 2018

Url 2, http://www.kartalkentder.org/tr/38764/Tarihsel-Gelisim Erişim Tarihi: 5 Aralık 2017

Url 3, https://ru.pinterest.com/pin/700591285754563953/ Erişim Tarihi: 8 Aralık 2017

Url 4, http://www.mimdap.org/?p=98350 Erişim Tarihi: 7 Aralık 2017

Url 5, http://www.marmaragundem.org/dragos-turistik-mobese-kameralari-izle.html Erişim Tarihi: 6 Mart 2018

Url 6, http://www.hurriyet.com.tr/gundem/dragos-artik-sit-alani-39120313 Erişim Tarihi: 25 Aralık 2017

Url 7, http://www.dragoss.com/ Erişim Tarihi: 27 Aralık 2017

Url 8, https://tr.pinterest.com/pin/393853929890878463/ Erişim Tarihi: 21 Şubat 2018 
Url 9, http://kentvedemiryolu.com/icinden-demiryolu-ustunden-ozellestirme-gecen-tekel/ Erişim Tarihi: 21 Şubat 2018

Url 10, http://mapio.net/pic/p-33805833/ Erişim Tarihi: 6 Mart 2018

Url 11, http://www.tutuneksper.org.tr/haberler/dernek-baskanimizin-roportaji Erişim Tarihi: 6 Mart 2018

\section{Görüşme/Sohbet}

Bora Çetin (Kamp Sakini) ile kişisel görüşme. İstanbul: Caddebostan, Ekim 2017.

DSİ (14. Bölge Müdürlüğü) ile kişisel görüşme. İstanbul: Çamlıca, Kasım 2017.

DSİ (14. Bölge Müdürlüğü Dragos Arşivi 2005) İstanbul.

Hülya Göksel (Dragos Arşivi 1996) İstanbul.

Hülya Göksel (Dragos Arşivi 1999) İstanbul.

Hülya Göksel (Dragos Doğayı Koruma Derneği Başkanı) ile kişisel görüşme. İstanbul: Kozyatağı, Nisan 2018.

Kartal Belediyesi (Bilgi İşlem Müdürlüğü ve Plan Proje Müdürlüğü) ile kişisel görüşme. İstanbul: Kartal, Kasim 2017.

Mehmet Öztürk (DSİ Personeli) ile kişisel görüşme. İstanbul: Çamlıca, Ocak 2018.

Merve Ertem (Mimar) ile kişisel görüşme. İstanbul: Dragos, Aralık 2017.

PTT (Yapı ve Teknik İşler Müdürlüğü Dragos Arşivi 2015) İstanbul.

Tuna Derin (Dragos Arşivi 1980) İstanbul.

Tuna Derin (PTT Eğitim Merkezi Müdürü) ile kişisel görüşme. İstanbul: Acıbadem, Aralık 2017. 